\title{
Influences of the 2010 Eyjafjallajökull volcanic plume on air quality in the northern Alpine region
}

\author{
K. Schäfer ${ }^{1}$, W. Thomas ${ }^{2}$, A. Peters ${ }^{3}$, L. Ries ${ }^{4}$, F. Obleitner ${ }^{5}$, J. Schnelle-Kreis ${ }^{6}$, W. Birmili ${ }^{7}$, J. Diemer ${ }^{8}$, W. Fricke ${ }^{2}$, \\ W. Junkermann ${ }^{1}$, M. Pitz ${ }^{3,10}$, S. Emeis ${ }^{1}$, R. Forkel ${ }^{1}$, P. Suppan ${ }^{1}$, H. Flentje ${ }^{2}$, S. Gilge ${ }^{2}$, H. E. Wichmann ${ }^{3}$, \\ F. Meinhardt ${ }^{4}$, R. Zimmermann ${ }^{6,9}$, K. Weinhold ${ }^{7}$, J. Soentgen ${ }^{10}$, C. Münkel ${ }^{11}$, C. Freuer ${ }^{12}$, and J. Cyrys ${ }^{3,10}$ \\ ${ }^{1}$ Karlsruhe Institute of Technology (KIT), Institute for Meteorology and Climate Research, Atmospheric Environmental \\ Research (IMK-IFU), Garmisch-Partenkirchen, Germany \\ ${ }^{2}$ German Meteorological Service (DWD), GAW-Global Station Hohenpeissenberg, \\ Meteorological Observatory (HPB), Germany \\ ${ }^{3}$ Helmholtz Zentrum München, German Research Center for Environmental Health (HMGU), \\ Institutes of Epidemiology I and II (Epi), Neuherberg, Germany \\ ${ }^{4}$ Federal Environmental Agency (UBA), GAW-Global Station Zugspitze (ZSF), Germany \\ ${ }^{5}$ Innsbruck University, Institute of Meteorology and Geophysics (IMGI), Innsbruck, Austria \\ ${ }^{6}$ Helmholtz Zentrum München, German Research Centre for Environmental Health (HMGU), Cooperation Group "Analysis \\ of Complex Molecular Systems", Joint Mass Spectrometry Center, Neuherberg, Germany \\ ${ }^{7}$ Leibniz Institute for Tropospheric Research (IfT), Leipzig, Germany \\ ${ }^{8}$ Bavarian Environment Agency (LfU), Augsburg, Germany \\ ${ }^{9}$ University of Rostock, Institute of Chemistry, Chair of Analytical Chemistry, Joint Mass Spectrometry Center, \\ Rostock, Germany \\ ${ }^{10}$ University of Augsburg (UA), Environment Science Centre (WZU), Augsburg, Germany \\ ${ }^{11}$ Vaisala GmbH, Hamburg, Germany \\ ${ }^{12}$ German Meteorological Service (DWD), Regional Centre München, Germany
}

Received: 11 February 2011 - Published in Atmos. Chem. Phys. Discuss.: 16 March 2011

Revised: 9 June 2011 - Accepted: 3 August 2011 - Published: 23 August 2011

\begin{abstract}
A series of major eruptions of the Eyjafjallajökull volcano in Iceland started on 14 April 2010 and continued until the end of May 2010. The volcanic emissions moved over nearly the whole of Europe and were observed first on 16 April 2010 in Southern Germany with different remote sensing systems from the ground and space. Enhanced $\mathrm{PM}_{10}$ and $\mathrm{SO}_{2}$ concentrations were detected on 17 April at mountain stations (Zugspitze/Schneefernerhaus and Schauinsland) as well as in Innsbruck by in situ measurement devices. On 19 April intensive vertical mixing and advection along with clear-sky conditions facilitated the entrainment of volcanic material down to the ground. The subsequent formation of a stably stratified lower atmosphere with limited mixing near the ground during the evening of 19 April led to an additional enhancement of near-surface particle concentrations.
\end{abstract}

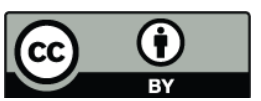

Correspondence to: K. Schäfer (klaus.schaefer@kit.edu)
Consequently, on 19 April and 20 April exceedances of the daily threshold value for particulate matter $\left(\mathrm{PM}_{10}\right)$ were reported at nearly all monitoring stations of the North Alpine foothills as well as at mountain and valley stations in the northern Alps. The chemical analyses of ambient $\mathrm{PM}_{10}$ at monitoring stations of the North Alpine foothills yielded elevated Titanium concentrations on 19/20 April which prove the presence of volcanic plume material. Following this result the $\mathrm{PM}_{10}$ threshold exceedances are also associated with the volcanic plume. The entrainment of the volcanic plume material mainly affected the concentrations of coarse particles $(>1 \mu \mathrm{m})-$ interpreted as volcanic ash - and ultrafine particles $(<100 \mathrm{~nm})$, while the concentrations of accumulation mode aerosol $(0.1-1 \mu \mathrm{m})$ were not changed significantly. With regard to the occurrence of ultrafine particles, it is concluded that their formation was triggered by high sulphuric acid concentrations which are necessarily generated by the photochemical processes in a plume rich in sulphur dioxide under high solar irradiance. It became evident that

Published by Copernicus Publications on behalf of the European Geosciences Union. 
during the course of several days, the Eyjafjallajökull volcanic emissions influenced the near-surface atmosphere and thus the ambient air quality. Although the volcanic plume contributed to the overall exposure of the population of the northern Alpine region on two days, only minor effects on the exacerbation of respiratory and cardiovascular symptoms can be expected.

\section{Introduction}

In the past, the Laki fissure eruptions of 1783-1784 in Iceland had a major impact on air quality in Central Europe. It has been estimated that during these eruptions approximately 122 megatons $(\mathrm{Mt})$ of sulphur dioxide $\left(\mathrm{SO}_{2}\right), 15 \mathrm{Mt}$ of hydrogen fluoride (HF) and $7 \mathrm{Mt}$ of hydrochloric acid $(\mathrm{HCl})$ were released into the atmosphere (Thordarson and Self, 1993, 2003). $\mathrm{SO}_{2}$ was rapidly removed from the relatively moist troposphere by forming about $200 \mathrm{Mt}$ of sulphuric acid $\left(\mathrm{H}_{2} \mathrm{SO}_{4}\right)$ and finally sulphate aerosol particles which were present over the northern hemisphere as an aerosol-rich fog for more than 5 months (Thordarson and Self, 2003). This fog led directly to a short-term climate cooling (WilliamsJones and Rymer, 2000; Hansen et al., 1992; Parker et al., 1996) and acid rain in Europe. HCl and HF damaged terrestrial biotas occurred not only in Iceland but on the European continent by reducing plant growth and enhancing the acidification of the soils. Fluor was stored in the food chain which led to high livestock mortality and the bone disease fluorosis in humans.

Volcanic emissions are currently in the focus of atmospheric research as from 14 April 2010 until the end of May 2010 a series of major eruptions of another volcano in Iceland, the Eyjafjallajökull, occurred. Due to a steady north-westerly air flow during the first active period from 14 April to 25 April, volcanic emissions (see e.g. for emission characterization Langmann et al., 2011; for emission estimation Stohl et al., 2011; for $\mathrm{SO}_{2}$ Thomas and Prata, 2011) moved over nearly the whole European continent (e.g. from air-borne measurements, see Schumann et al., 2011) and handicapped aviation. North German airports were closed from the evening of 15 April, the airport at München stopped operations on 16 April followed by an almost total closure of the European air space until 20 April. On 16 April, various remote sensing (lidar, ceilometer, photometer) and on 17 April, in situ measurement systems at mountain stations (Zugspitze/Schneefernerhaus and Schauinsland) detected the volcanic cloud in Southern Germany (Emeis et al., 2011; Flentje et al., 2010; Gasteiger et al., 2011). Mountain hikers, e.g. at Arlberg at about $2500 \mathrm{~m}$ above sea level (a.s.l.), reported an odour of sulphur (personal communication C. Plass-Duelmer, DWD/HPB, 2010) on 17 April. During 19 April and 20 April, high concentrations of particulate matter (particle sizes smaller than $10 \mu \mathrm{m}-\mathrm{PM}_{10}$ ) were re- ported at nearly all monitoring stations in the North Alpine forelands as well as at stations in the northern Alps. $\mathrm{SO}_{2}$ concentrations were also enhanced at many monitoring stations. All over Europe, monitoring stations observed enhanced air pollutant concentrations.

To consider the strength of the influences of the 2010 Eyjafjallajökull volcanic plume on ambient air composition the legally relevant criterion of the European Union air quality directive 2008/50/EC (for Germany, see BImSchV, 2010) is the basis. This directive sets a 24-h $\mathrm{PM}_{10}$ mass concentration threshold value of $50 \mathrm{\mu g} \mathrm{m}^{-3}$ which must not be exceeded more than 35 times a calendar year at any air quality monitoring station. The annual threshold value of $\mathrm{PM}_{10}$ is $40 \mu \mathrm{g} \mathrm{m}^{-3}$ and the annual target value of particles with sizes smaller than $2.5 \mu \mathrm{m}\left(\mathrm{PM}_{2.5}\right)$ is $25 \mu \mathrm{g} \mathrm{m}^{-3}$. Correspondingly, a 24-h threshold value of $125 \mu \mathrm{g} \mathrm{m}^{-3}$ for $\mathrm{SO}_{2}$ and an 8 -h target value of $120 \mu \mathrm{g} \mathrm{m}^{-3}$ for ozone apply, where only 3 and 25 exceedances are allowed per year, respectively. Further threshold values currently exist for nitrogen dioxide $\left(\mathrm{NO}_{2}\right)$, carbon monoxide $(\mathrm{CO})$, benzene and lead $(\mathrm{Pb})$ and from 2013 on, for arsenic (As), cadmium (Cd), nickel (Ni), and benzo(a)pyrene. According to 2008/50/EC, days with threshold value exceedances which are attributable to natural sources e.g., volcanic eruptions or Saharan dust are reported to the European Commission. These days are then not counted for the 2008/50/EC regulation. Evidence for the contribution of natural sources can for example be provided by elemental analysis of $\mathrm{PM}_{10}$ samples. Therefore, environmental agencies analysed the elemental composition of particle samples and studied the $\mathrm{PM}_{10}$ and $\mathrm{SO}_{2}$ concentrations in order to quantify the influence of the Eyjafjallajökull volcano on air quality (see e.g. Krabbe et al., 2010). Colette et al. (2010) performed a corresponding investigation in France.

The study of this volcano eruption event on the basis of existing monitoring networks allows us to determine the potential impacts of volcanic plumes on air quality and the corresponding health risks in the northern Alpine region.

\section{Objectives and study area}

This paper provides, in a first step, a documentation of the horizontal and vertical distribution of suspended particles of a volcanic origin in the northern Alpine region following the eruption of Eyjafjallajökull and the associated meteorological transport. The analysis is based on a physical and chemical characterisation of particles and gases at multiple groundbased observation sites as well as remote sensing data:

- optical observations from the ground and space;

- time series of $\mathrm{PM}_{10}$ and $\mathrm{SO}_{2}$ mass concentrations;

- particle number size distributions (PSD) and particle number concentrations (PNC);

- multi-elemental composition of $\mathrm{PM}_{10}$ filter samples; 
Table 1. All stations and in situ measurement methods used.

\begin{tabular}{lrlllll}
\hline station & altitude & main operating & type $^{5}$ & \multicolumn{3}{c}{ measurement methods } \\
\cline { 5 - 7 } & ma.s.l. & institution & & $\mathrm{PM}_{10}$ & $\mathrm{PNC}$ & $\mathrm{SO}_{2}$ \\
\hline AUHS & 500 & HMGU/UA $^{1}$ & urban bg. & TEOM & TDMPS & - \\
IBK & 570 & UBA-AT $^{2}$ & urban bg. & FH62I-R & - & APSA 360 \\
HPB & 980 & DWD $^{3}$ & regional bg. & TEOM & TD SMPS & TE 43 CTL \\
SSL & 1200 & UBA-D $^{4}$ & regional bg. & FH62I-R & TD SMPS & TE 43 CTL \\
ZSF & 2670 & UBA-D $^{4}$ & regional bg. & FH62I-R & TD SMPS & TE 43 CTL \\
\hline
\end{tabular}

${ }^{1}$ Helmholtz Zentrum München/University of Augsburg

2 Austrian Umweltbundesamt

${ }^{3}$ Deutscher Wetterdienst

${ }^{4}$ German Umweltbundesamt

5 urban bg. = urban background, regional bg = regional background

- chemical analysis of wet deposition;

- air-borne measured parameters like spectral optical absorption and ozone concentrations.

This study focuses on the primary event lasting from 17 April to 20 April 2010. In particular, we focus on the development of the near-surface concentrations of $\mathrm{SO}_{2}$ and $\mathrm{PM}_{10}$ during this period in Southern Germany and the northern Austrian Alps. Southern Germany and the neighbouring Tyrol (Austria) are characterized by both flat lands and mountainous areas. Therefore, possible mixing processes like entrainment, convection, advection and turbulent mixing are considered.

The study area is delineated by the Black and Bavarian Forests to the West and East and the regions around Nürnberg and Innsbruck to the North and South, respectively (see Fig. 1) and relates to that of Emeis et al. (2011). This region was characterized by the highest $\mathrm{PM}_{10}$ concentrations at ground level within Germany and Austria during the considered temporal period. The following measurement sites have been selected (see Table 1 also): Schauinsland (SSL), Augsburg (AUHS), Hohenpeissenberg (HPB), Zugspitze/Schneefernerhaus (ZSF) and Innsbruck (IBK). Some more details on the development within Austria are given in the Supplement.

Finally, the potential influence of the volcanic material with respect to human health aspects is discussed.

\section{Data, instruments and methods}

This work is based on analyses of ground-based and airborne in situ measurements, remote sensing derivatives and synoptic maps. All data were considered as hourly means for continuous monitoring instruments on the time basis Central European Time (CET).

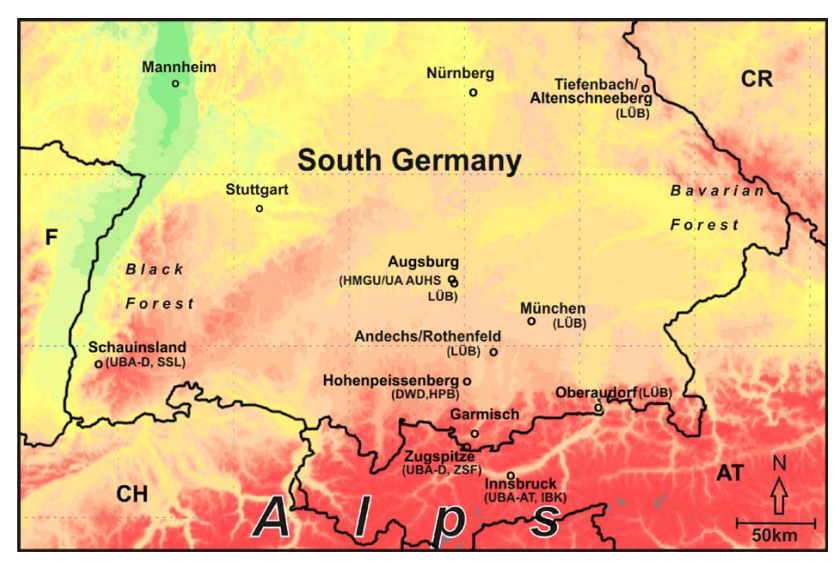

Fig. 1. Contour map with altitude indicated by different colours from green to red (up to about $3000 \mathrm{~m}$ a.s.l.) showing the positions of the Bavarian Air Monitoring Network (LÜB) sampling sites where daily $\mathrm{PM}_{10}$ samples were investigated (see Sect. 3.3 also and later in the text where the acronyms are used): Andechs/Rothenfeld (ADRO), Augsburg (Bürgermeister-Ulrich-Strasse) (AUBÜ), München (Landshuter Allee) (MÜLA), Oberaudorf (Inn valley motorway) (OBIA), Tiefenbach/Altenschneeberg (TBAL). Further sites include (see Table 1 also) Schauinsland (German Umweltbundesamt (UBA-D), SSL), Zugspitze/Schneefernerhaus (German Umweltbundesamt (UBA-D), ZSF), Hohenpeissenberg (Deutscher Wetterdienst (DWD), HPB), Innsbruck (Austrian Umweltbundesamt (UBA-AT), IBK) and Augsburg (Helmholtz Zentrum München/University of Augsburg (HMGU/UA), AUHS).

\subsection{Ground-based in situ measurements}

An overview of the selected key monitoring sites, including their characterization and instrumentation, is given in Table 1.

$\mathrm{PM}_{10}$ concentrations were measured by beta-radiation absorption measurements with Thermo Fisher Scientific Inc., model FH62I-R, Franklin, USA at IBK, SSL and ZSF, whereas a tapered element oscillating microbalance (TEOM) 
measurement, Rupprecht and Patashnick, model 1400 a, East Greenbush, USA was used at AUHS and HPB.

PSD were recorded at AUHS, HPB, SSL and ZSF using electromobility spectrometers. These measurements are part of the German Ultrafine Aerosol Network (GUAN) that has been operational since 2008 at various sites in Germany (Birmili et al., 2009). At AUHS, a twin differential mobility particle sizer (TDMPS), IfT, Leipzig, Germany (detectable particle size range from 3 to $800 \mathrm{~nm}$ ) is deployed in conjunction with an aerodynamic particle sizer (APS), TSI Inc., model 3321, Shoreview, USA (detectable particle size range from 0.8 to $10 \mu \mathrm{m})$. At HPB, SSL and ZSF scanning mobility particle sizers (SMPS), TSI Inc., model 3936, Shoreview, USA are operated with a detectable size range from 10 to $800 \mathrm{~nm}$ (HPB, SSL) and from 10 to $600 \mathrm{~nm}$ (ZSF), respectively. At HPB, SSL and ZSF, a thermodenuder with $300^{\circ} \mathrm{C}$ (TD), TSI Inc., Shoreview, USA is running upstream of the electromobility spectrometers during each second sample to evaporate volatile PM components. Quality assurance procedures at AUHS are documented in Pitz et al. (2008a, b), while Wiedensohler et al. (2010) is a reference for the quality of the SMPS instruments deployed at HPB, SSL, and ZSF. Mannschreck et al. (2004) provides more information about the measurement program at HPB.

In addition, the in situ aerosol forward and backscattering coefficient and Angstroem exponent were measured at SSL and HPB by a three wavelength integrating nephelometer, TSI Inc., model TSI 3563, Shoreview, USA. The total PNC was measured at ZSF with both a butanol-based and water-based condensation particle counter (CPC), TSI Inc., model 3025a, Shoreview, USA.

\subsection{Remote sensing and air-borne instruments and data}

Although the majority of the collected data is based on in situ observations, we also analysed data sets provided by the following remote sensing systems:

- METEOSAT SEVIRI images from geostationary orbit (HPB).

- Ceilometer CL31 (backscatter profiles at $910 \mathrm{~nm}$; Emeis and Schäfer, 2006) at AUHS (KIT/IMK-IFU), see Emeis et al. (2011) for further information about the ceilometer network of the DWD CEILONET as well as lidar measurements.

- Ultralight aircraft flight (KIT/IMK-IFU) in the late afternoon of 19 April in the area south-east of Augsburg, see also Emeis et al. (2011).

Since SEVIRI imagery is further used for discussing the synoptic situation, the generation of these images and their physical meaning is briefly explained. The detection of ash and dust in the atmosphere is possible by using infra-red satellite imagery based on red-green-blue (RGB) colour composites
(Schmetz et al., 2002) from the SEVIRI satellite radiometer. Due to the high spatial and temporal resolution of SEVIRI, dust outbreaks, fire plumes and volcanic plumes can often be tracked and monitored for hours and even days. The European Organisation for the Exploitation of Meteorological Satellites (EUMETSAT) provides the so-called "ash" and "dust" products at hourly resolution as RGB-images in a 5 day rolling archive (http://oiswww.eumetsat.int/IPPS/html/ MSG/RGB/). The RGB "ash product" is generated using the following SEVIRI channels ( $\mathrm{Ch}$ ) and channel combinations:

red $=$ radiance difference $(\mathrm{Ch} 12.0 \mu \mathrm{m}-\mathrm{Ch} 10.8 \mu \mathrm{m})$; this is the prime detection method for ash and dust in the atmosphere (also used for cloud detection);

green $=$ radiance difference $(\mathrm{Ch} 10.8 \mu \mathrm{m}-\mathrm{Ch} 8.7 \mu \mathrm{m})$, partially sensitive to $\mathrm{SO}_{2}$;

blue $=$ Ch $10.8 \mu \mathrm{m}$, cloud detection .

The flight of the ultralight aircraft was performed about $10 \mathrm{~km}$ north-west of the airport of Jesenwang $\left(48^{\circ} 10.46^{\prime}, \mathrm{N}\right.$, $11^{\circ} 10.50^{\prime} \mathrm{E}$, between München and Augsburg) on 19 April leaving at 14:40 for a vertical profile up to $4000 \mathrm{~m}$ a.s.l. and returning to the ground at 16:30. This location was selected with the objective to compare the measurements with the remote sensing and in situ observations in the surroundings. The instrumentation of the aircraft (Junkermann, 2001) includes an optical particle counter (OPC), Grimm, model 1.108 , Ainring, Germany with 15 size bins between $300 \mathrm{~nm}$ and $20 \mu \mathrm{m}$, an open path nephelometer, HSS Inc., AVMIII, Bedford, Mass., USA for extinction measurements, and a seven-wavelength aethalometer, MAGEE Scientific, model AE42, Berkeley, USA for the spectral characterisation of the aerosol absorption. Also the ozone concentration, temperature and dewpoint were detected. The additional CPC, TSI Inc., model 3010, Shoreview, USA was in operation only below $1200 \mathrm{~m}$.

Daily $\mathrm{PM}_{10}$ samples from five stations of the Bavarian Air Monitoring Network (LÜB), which are shown in Fig. 1, have been chemically analysed for volcanic material. The sampling sites have the following characteristics: Andechs/Rothenfeld (ADRO): regional background, Augsburg (Bürgermeister-Ulrich-Strasse) (AUBÜ): city background, München (Landshuter Allee) (MÜLA): traffic, Oberaudorf (Inn valley motorway) (OBIA): traffic, Tiefenbach/Altenschneeberg (TBAL): regional background.

Samples were collected during $24 \mathrm{~h}$ on quartz fibre filters (PALL TISSUQUARTZ 2500 QAO-UP, Lot 56276) by low volume samplers, Leckel, model SEQ47/50, Berlin, Germany. The elemental composition of the $\mathrm{PM}_{10}$ samples from the five sites was analysed by ICP-MS after microwave decomposition of the samples as described in DIN EN 14902 (2005).

Rain water was collected at HPB using a wet only sampler, Eigenbrodt, model NSA 181/KE, Königsmoor, Germany. The daily samples are changed at 07:30. They are 
analysed for ions using suppressed ion chromatography with a Dionex AS14 column for anions and a Dionex CS12 column for cations. The $\mathrm{pH}$ value is measured with a WTW pMX3000/pH meter and a Mettler Toledo InLab Science electrode, conductivity with a WTW LF3000 instrument and a WTW LR01/T electrode, both electrodes suited for low conductivities. The data are part of HPB's routine contribution to the Global Atmospheric Watch (GAW) programme as a Global Station and are quality controlled according to the GAW procedures.

$\mathrm{SO}_{2}$ concentration was measured by UV-fluorescence method with Thermo Fisher Scientific Inc., model TE 43 CTL, Waltham, USA at HPB, SSL and ZSF, whereas at IBK monitoring site Horiba, model APSA 360, Kyoto, Japan was used.

\section{Results of observations and interpretation}

\subsection{Synoptic Situation and transport of volcanic emissions}

On 14 April and 15 April, a North Atlantic high pressure system extended over the northern British Isles towards Southern Scandinavia and induced north-easterly winds over Central Europe (for more details and affects in Iceland, see Petersen, 2010). This favoured a rapid propagation of the volcanic plume across the North Sea to Germany and the Netherlands, as evidenced, e.g., by ceilometers that progressively detected the volcanic plume during its southbound motion at about 6-7 kma.s.l. (see Emeis et al., 2011). By 17 April, the centre of this high pressure system was located over Southern England and the main air flow continued from North-West to South-East. Since large parts of Central Europe were cloud-free during 17 April and partially also on 18 April, the volcanic plume could be tracked by hourly METEOSAT SEVIRI satellite imagery. Due to this tracking in space and time we are able to qualitatively distinguish the volcanic emissions from locally distributed dust in the study area. The Alpine area and large parts of south-western Germany and Switzerland were later affected by a low pressure system over the northern Adriatic Sea which brought clouds and rain showers to the area on 18 April and the following days, thus hampering observation of the volcanic plume by passive satellite instruments. This cyclonic system was mainly responsible for further dispersal of volcanic material in the area of interest.

A first weak sign of the eruption became visible in SEVIRI data, the so-called "ash product" as described in Sect. 3.2, from 14 April, 08:00 UTC while clear signs were apparent by 15 April, 15:00 UTC. Observational conditions were not optimal for passive satellite instruments since high clouds hampered the view of lower atmospheric levels. However, on 16 April, 00:00 UTC, the ash front was clearly identified over the North Sea (Fig. 2, upper panel) in a distance of al-
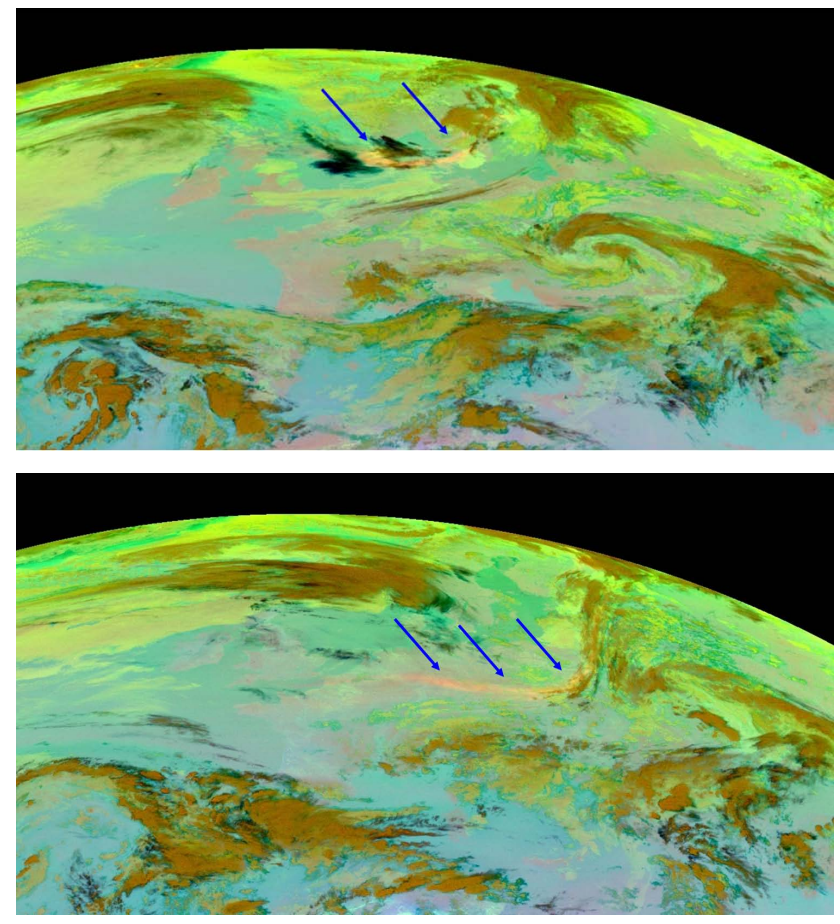

Fig. 2. METEOSAT SEVIRI "ash product" from 16 April, 00:00 UTC (upper panel). The bow-shaped volcanic plume is apparent over the North Sea between England and Southern Scandinavia. The same type of image from 16 April, 18:00 UTC (lower panel) shows ash signatures over the Benelux area, Germany, Poland and the Czech Republic. Blue arrows indicate the position of the volcanic plume which is colour-coded in orange.

ready about $1500 \mathrm{~km}$ from Iceland. The southern front of the volcanic plume was almost parallel to circles of latitude. Only nine hours later, the front line already passed the coastal zones of Germany and Poland and quickly moved across Germany. It further passed large parts of Poland, where the most southerly section of the front reached the Czech Republic and Slovakia in the late afternoon of 16 April (Fig. 2, lower panel). At this point it is evident that the curvature of the ash front had grown, indicating a differential propagation by different sections of the volcanic plume. The area of highest speed towards South-East is indicated by the right hand arrow in Fig. 2, lower panel. There, the ash plume is still visible as a narrow, elongated plume moving south-eastwards with the main air flow.

Another nine hours later (17 April, 00:00 UTC), the detection of the ash plume by means of SEVIRI imagery became more and more difficult. It appeared now as a thin layer across Germany and parts of Austria, including South-East of the Alps (Fig. 3, upper left panel, faint coloured layer). Surface winds were from north-easterly directions at the Alps (Fig. 3, middle panels) and the low pressure system over Northern Italy is apparent in the satellite image as well as 

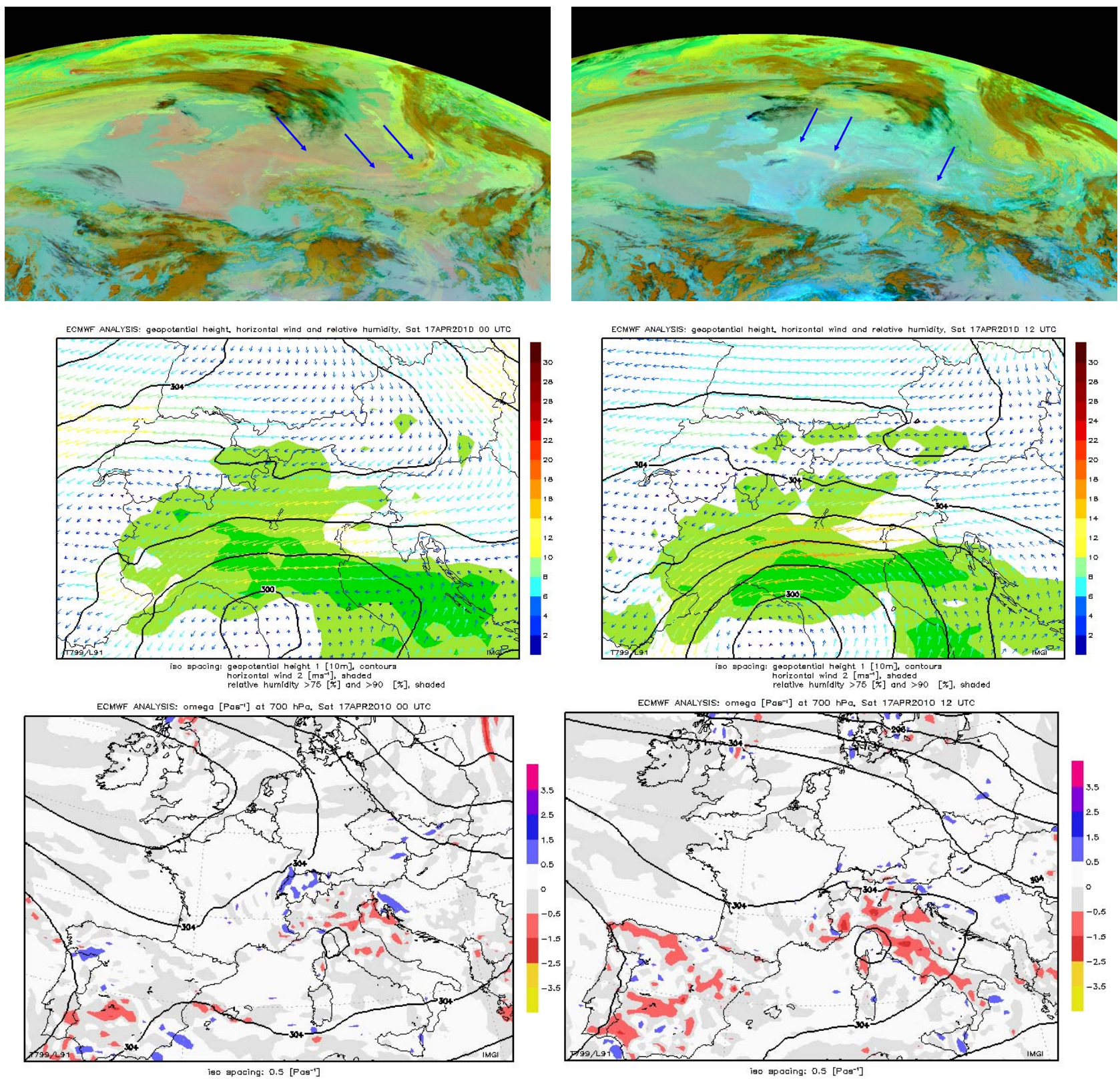

Fig. 3. Upper panels: METEOSAT SEVIRI "ash product" from 17 April, 00:00 UTC (left) and 17 April, 12:00 UTC (right). Blue arrows indicate the volcanic plume which is colour-coded in orange. High cloudiness (brownish) is apparent south of the Alps allocated to a cyclonic system over the Gulf of Genoa. Middle panels: $700 \mathrm{hPa}$ geopotential height (10 gpm contour lines), relative humidity ( $>90 \%$ in dark green) and horizontal wind (speed and direction, colour coded arrows in $2 \mathrm{~m} \mathrm{~s}^{-1}$ steps) taken from ECMWF analyses. Lower panels: $700 \mathrm{hPa}$ geopotential height ( 40 gpm contour lines) and vertical wind components (colour coded in steps of $0.5 \mathrm{Pas}^{-1}$ ).

in the relative humidity fields (Fig. 3, middle panels). The more rapid motion of parts of the plume towards South-East led to a more elongated front line across Europe (Fig. 3, upper right panel). The most eastern part of the volcanic plume initially passed the eastern Alpine area, while the western patches were to later slow down over south-western Germany and in Switzerland on 18 April. As a consequence of this di- lution, particle concentrations in the plume decreased and the ash signal in the satellite image became weaker. On 17 April, the ash plume covered all the stations in Southern Germany and Austria but became invisible for SEVIRI over large parts of this area due to reduced concentration levels, with clouds hampering the detection. On 17 April, 12:00 UTC, remnants of the ash front are not only still visible over south-eastern 

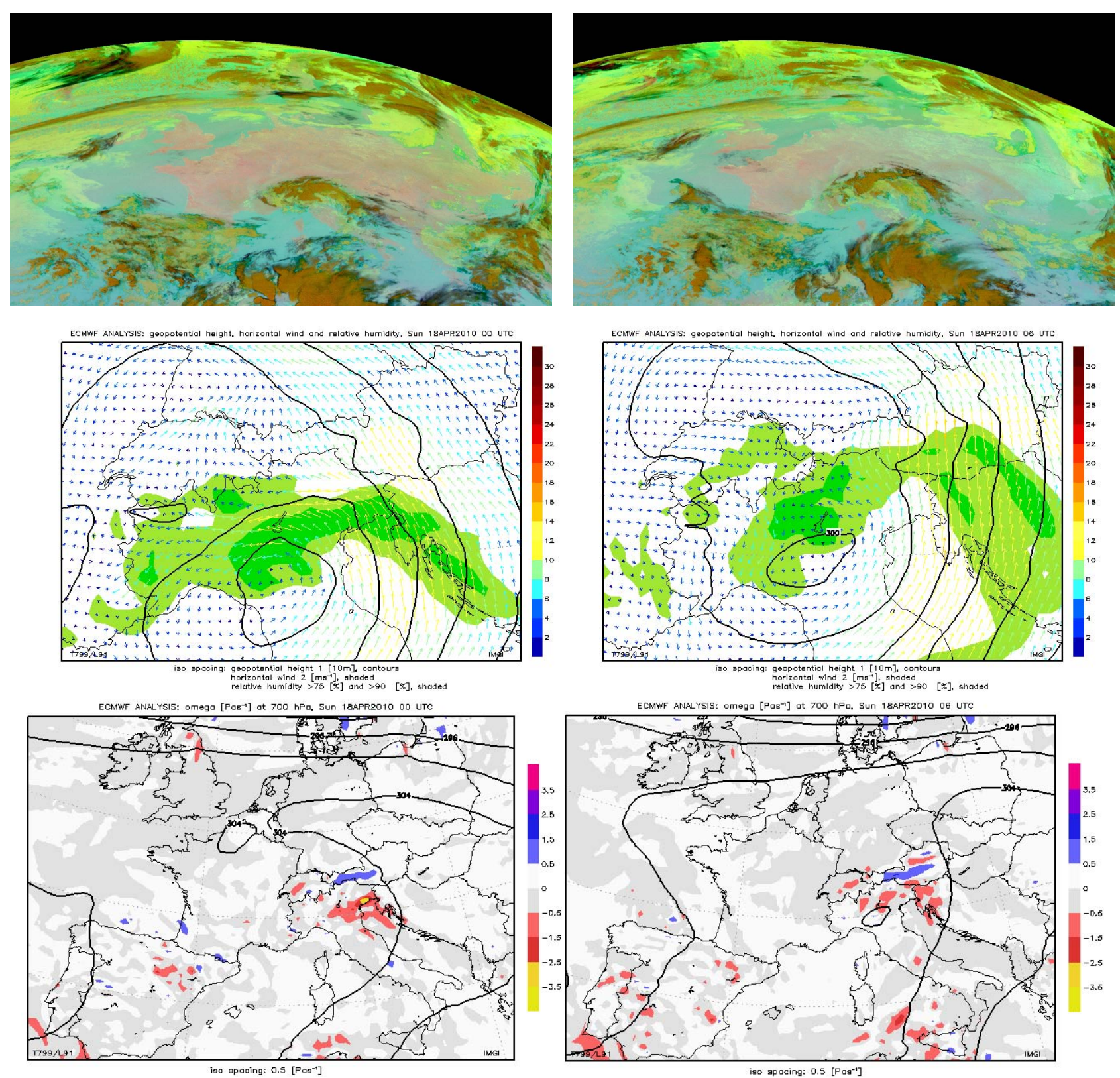

Fig. 4. Upper panels: METEOSAT SEVIRI "ash product” from 18 April, 00:00 UTC (left) and 18 April, 06:00 UTC (right). High cloudiness (brownish) is apparent south of the Alps allocated to a cyclonic system over the Gulf of Genoa (see also Fig. 3). Middle panels: 700 hPa geopotential height (10 gpm contour lines), relative humidity ( $>90 \%$ in dark green) and horizontal wind (speed and direction, colour coded arrows in $2 \mathrm{~m} \mathrm{~s}^{-1}$ steps) taken from ECMWF analyses. Lower panels: $700 \mathrm{hPa}$ geopotential height (40 gpm contour lines) and vertical wind components (colour coded in steps of $0.5 \mathrm{Pas}^{-1}$ ).

Austria and Slovenia, but also over France (see arrows in Fig. 3, upper right panel). During 17 April, the low pressure system over northern Italy became more and more important for the spatial and temporal evolution of the volcanic plume north of the Alps. As seen in Fig. 3 (middle panels), the wind direction over the northern Alpine area turned from northeast to easterly directions. The southern Alpine area experi- enced south-easterly flow inducing cloudiness and some precipitation. Signs of subsiding air masses (blue areas in Fig. 3, lower right panel) are noted along the northern fringes of the Alps on 17 April, 12:00 UTC (Fig. 3, lower panels) which supports the conclusions drawn from the ceilometer data as discussed in Sect. 4.4.1. 
Signatures of the volcanic plume are hardly visible in the satellite images from 18 April (Fig. 4, upper panels). This is due to the increasing influence of the low pressure system south of the Alps hampering the direct observation of the volcanic plume over Tyrol and the northern Alpine area. The further approach of the cyclonic system induced southerly winds across the Alps contrasting the north-easterly winds the day before (Fig. 4, middle right panel). Some foehnlike impact on the air flow on 18 April (subsidence in the North of the Alps, blue areas in Fig. 4) is suggested by the banded structure of vertical velocity and short-term southerly winds at ZSH during noon. However, the foehn did not break through to e.g. the Inn valley bottom. However, the associated cyclonic system rapidly crossed the Alps and lost control over the air flow in the area of interest. The remaining volcanic material over the southern Benelux area and neighbouring France again moved slowly in a south-easterly direction, but satellite images largely lost track of the material due to cloudiness and the overall lower particle concentrations. A weak "ash" signature was found over France on 18 April (not shown) which was still present in the area on 19 April and moving to the South-East. Although observational conditions over Germany improved again on 19 April, the ash load of the atmosphere was no longer visible from space. This was mainly due to stronger downward mixing to the ground and thus dilution, as it will be discussed later. Westerly winds dominated in the following days when ash remnants over Europe were no longer detected by passive satellite instruments.

ZSF detected the first enhanced $\mathrm{SO}_{2}$ and $\mathrm{PM}_{10}$ concentrations on 17 April as the central Alpine station Jungfraujoch (JFJ) in $3580 \mathrm{~m}$ a.s.l. also while JFJ registered the maximum influences of the volcanic plume on 18 April (see Bukowiecki et al., 2011). This is in line with the satellite observations. At that time (18 April), the volcanic plume was already mixed into the PBL over the northern Alpine area and Tyrol. Even weak precipitation observed on 18 April and 20 April in the northern Alpine area at ZSF and HPB did not completely wash out the particles (see e.g. Flentje et al., 2010). A second maximum of $\mathrm{SO}_{2}$ and $\mathrm{PM}_{10}$ concentrations was observed on 19 April at ZSF and JFJ also. An enhanced PNC was recorded at HPB until 22 April.

\subsection{Spatio-temporal evolution of the volcanic plume}

Figure 5 shows the spatial distribution of daily $\mathrm{PM}_{10}$ concentration means in Germany for the time period from 17 April to 20 April. These maps were generated by UBA-D on the basis of their regional ground-based air quality monitoring network. The network does not include stations in the higher Alpine regions, so that the results of the interpolation for the Alpine region are affected by large uncertainties. For example the high daily $\mathrm{PM}_{10}$ concentrations on 17 April observed at SSL and ZSF are not visible on the UBA-D map for this day. The highest daily averaged $\mathrm{PM}_{10}$ concentrations of about $100 \mu \mathrm{g} \mathrm{m}^{-3}$ were reached at measurement stations in the area of Stuttgart and Karlsruhe on 19 April and the maximum regional daily average of about $60 \mu \mathrm{g} \mathrm{m}^{-3}$ was determined in the very south-western part of Baden-Württemberg. On 20 April the daily averaged $\mathrm{PM}_{10}$ concentrations decreased in that region but increased in the area of Augsburg and München up to maximum values of about $60 \mu \mathrm{g} \mathrm{m} \mathrm{m}^{-3}$.

The $\mathrm{PM}_{10}$ and $\mathrm{SO}_{2}$ concentrations at four core measurement stations IBK, SSL, HPB and ZSF peak at about the same time (17/18 April and 19/20 April, see Fig. 6). Only during the second episode (19/20 April) elevated $\mathrm{PM}_{10}$ concentrations were observed at AUHS site (Fig. 6).

The highest short-term concentrations of $\mathrm{PM}_{10}$ of more than $140 \mu \mathrm{g} \mathrm{m}^{-3}$ were observed at SSL on 19 April. The $\mathrm{PM}_{10}$ concentrations at ZSF were only half of the values observed at SSL, which is presumably due to the scavenging of coarse aerosols by precipitation. $\mathrm{PM}_{10}$ concentrations up to $100 \mu \mathrm{g} \mathrm{m}^{-3}$ were measured in the city of Freiburg (ca. $10 \mathrm{~km}$ north-west of SSL and approximately $1000 \mathrm{~m}$ lower, see Fig. 5) and caused a threshold value exceedence there. Also, IBK reported $\mathrm{PM}_{10}$ concentrations higher than $50 \mu \mathrm{g} \mathrm{m}^{-3}$ for more than $12 \mathrm{~h}$ during both events indicating the presence of the volcanic plume at least $50 \mathrm{~km}$ south of ZSF. Note the Supplement documenting some details about the development across the Alps and the eastern regions of Austria. The influence of the mountains upon the air mass transport is further discussed by Emeis et al. (2011). At HPB, $\mathrm{PM}_{10}$ concentrations increased from $20 \mu \mathrm{g} \mathrm{m}^{-3}$ to $40 \mu \mathrm{g} \mathrm{m}^{-3}$ (peaks about $50 \mu \mathrm{g} \mathrm{m}^{-3}$ ) on 17 April and remained elevated until 23 April. These values are quantitatively in line with the results from $\mathrm{JFJ}$ (concentrations of $\mathrm{PM}_{10}$ around $30 \mu \mathrm{g} \mathrm{m}^{-3}$ and $\mathrm{SO}_{2}$ almost $4 \mu \mathrm{g} \mathrm{m}^{-3}$ on 18 April as reported by Bukowiecki et al., 2011).

Apart from urban anthropogenic emissions, secondary ultrafine particles (UFP - particle in the size range 3-100 nm) are regularly formed in the atmosphere during mid-day secondary particle formation bursts (Kulmala et al., 2004). In Central Europe, such bursts seem to be triggered by the photochemical formation of $\mathrm{H}_{2} \mathrm{SO}_{4}$, originating mainly from the oxidation of $\mathrm{SO}_{2}$ (Birmili et al., 2003; Paasonen et al., 2010). Volcanoes are a major source of $\mathrm{SO}_{2}$ in the atmosphere (see also Thomas and Prata, 2011). The Institute of Earth Sciences of the University of Iceland publishes current $\mathrm{SO}_{2}$ gas fluxes from volcanoes in Iceland (http://www.earthice.hi.is/page/IES-EY-CEMCOM). It is obvious from measured $\mathrm{SO}_{2}$ values (Fig. 6, maximum of $16 \mu \mathrm{g} \mathrm{m}^{-3}$ at SSL) that the volcanic plume contained $\mathrm{SO}_{2}$ at much higher concentrations than being typical for the tropospheric background. Assuming a $\mathrm{SO}_{2}$ oxidation rate to sulphur trioxide $\left(\mathrm{SO}_{3}\right)$ and the subsequent reaction with water vapour of $3 \% \mathrm{~h}^{-1}$ from laboratory and field experiments (Warneck, 1988) and taking into account a transport time of 3 days, a significant amount of initial $\mathrm{SO}_{2}$ was likely converted to $\mathrm{H}_{2} \mathrm{SO}_{4}$ and sulphate in the volcanic plume. This hypothesis is supported by prevailing clear-sky conditions over 

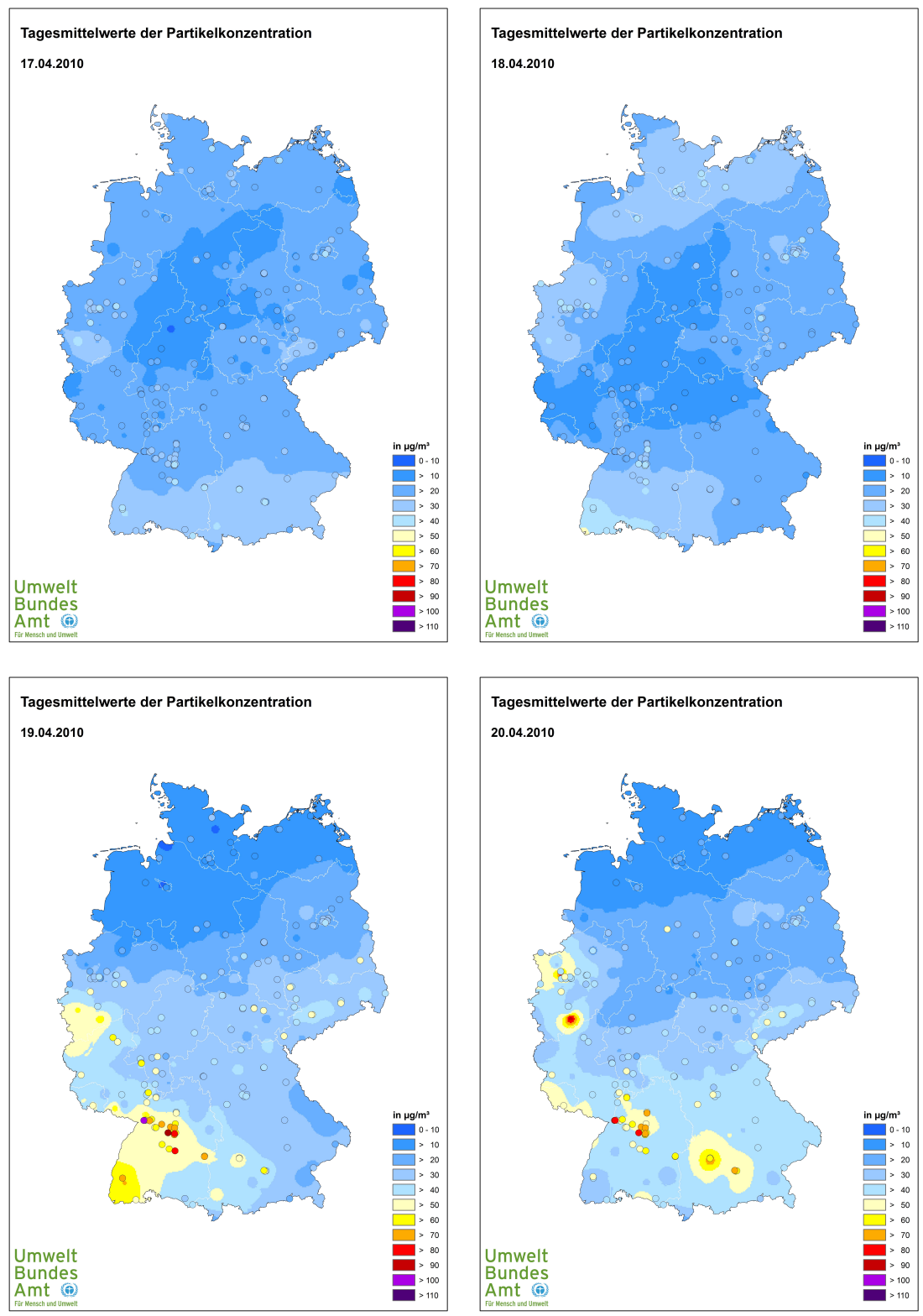

Fig. 5. Spatial distribution of daily mean $\mathrm{PM}_{10}$ concentrations in Germany for the time period 17 April (upper panel left), 18 April (upper panel right), 19 April (lower panel left) and 20 April (lower panel right) on the basis of monitoring network data (German Umweltbundesamt Federal Environment Agency of Germany, http://www.env-it.de/umweltbundesamt/luft-daten/index.html). The monitoring sites are indicated by circles. Different concentration ranges in $\mu \mathrm{g} \mathrm{m}^{-3}$ are given by different colours as indicated in the maps. The network does not include stations in higher Alpine regions, corresponding to the southern fringe of the map.

Central Europe on 17 April and 18 April which facilitate hydroxyl $(\mathrm{OH})$ radical production and their subsequent reaction with $\mathrm{SO}_{2}$ (for more information about these processes, see Hamed et al., 2010; Kazil et al., 2010). Under non-volcanic conditions substantial contributions to secondary particle formation additionally stem from volatile organic compounds (VOC) as well as nitrogen oxides and ammonia as discussed by e.g. Kulmala et al. (2004). But during the volcanic plume influence at ZSF and HPB no increase of those pollutants was observed (Flentje et al., 2010) so that the UFP formation from these precursors is unlikely. Following this Flentje et al. (2010) pointed out that $\mathrm{SO}_{2}$, due to its tropospheric life time of several days, can be seen as an excellent tracer for long-range transport of volcanic material. However, as $\mathrm{SO}_{2}$ is emitted by natural (volcanoes, oceans) as well as anthropogenic sources it is only true for areas which are 
not strongly influenced by anthropogenic emissions. Thus, the $\mathrm{SO}_{2}$ levels are elevated during the two episodes at all measurement sites except Augsburg (Fig. 6). There are no $\mathrm{SO}_{2}$ measurements available at AUHS, however, no increase of $\mathrm{SO}_{2}$ concentration was observed at Augsburg monitoring sites operated by LÜB (data not shown). $\mathrm{SO}_{2}$ concentration at ZSF rose sharply on 17 April between 08:00 and 12:00 from background levels up to $8 \mu \mathrm{g} \mathrm{m}^{-3}$, thus exceeding the maximum hourly concentrations observed between 2000 and 2007 in April (to be comparable to this volcanic plume event) as shown in Fig. 6.

Flentje et al. (2010) observed also high correlation between the $\mathrm{SO}_{2}$ levels and PNC of particles larger than $3 \mathrm{~nm}$. It was especially pronounced at ZSF, whereas at HPB the clear signal of PNC was partially masked by enhanced anthropogenic background. Time series of ultrafine PNC in the size range $10-30 \mathrm{~nm}$ and $30-100 \mathrm{~nm}$ observed at the four core measurement sites AUHS, SSL, HPB and ZSF in our study are shown in Fig. 7. On 17 April, ultrafine PNC levels rose from background concentrations to elevated levels at ZSF shortly before 11:00 and two hours later at SSL. As discussed by Emeis et al. (2011), the delay at SSL is probably due to the much lower height of this monitoring site (1200 $\mathrm{m}$ a.s.l. compared to the $2670 \mathrm{~m}$ a.s.l. of ZSF). The signal peaks between 15:00 and 16:00 at both sites with a PNC of more than 16000 and 12000 particles $\mathrm{cm}^{-3}$ at SSL and ZSF, respectively (size range $10-100 \mathrm{~nm}$ ). During the following hours, the measured ultrafine PNC decreased to a relatively low level of less than 4000 particles $\mathrm{cm}^{-3}$ at SSL at 20:00, and later on also at ZSF. The latter PNC is rather typical for ZSF if the station is within the PBL.

After reaching their first maximum, the ultrafine PNC decreased on 18 April, but showed a second and stronger maximum in the afternoon of 19 April. This peak occurred between 12:00 and 13:00 at SSL, and four hours later (between 16:00 and 18:00) at HPB and ZSF. The ultrafine PNC at AUHS showed a maximum between 13:00 and 14:00, but the association of this peak with volcanic material is partially masked by the elevated regional and urban background level in the urban air of Augsburg. The ultrafine PNC were higher during the second episode on 19 April than during the first episode on 17 April at all four locations AUHS, SSL, HPB and ZSF. Similar features were observed at Austrian sites measuring size discriminated particle concentrations (see Supplement).

The influence of volcanic ash on the time series of particles in the size fraction from 100 to $800 \mathrm{~nm}$ is not visible (data not shown). Obviously the effect of the volcanic eruption on particles in this size range (given there was one) was very small and it didn't produce any prominent peak in PNC. This is in agreement with near-source (Ilyinskaya et al., 2011) and JFJ (Bukowiecki et al., 2011) observations during that time showing a bimodal distribution of the suspended aerosol mass with high particle abundances around $0.2 \mu \mathrm{m}$ and at $1-4 \mu \mathrm{m}$.
Further in situ measurements at HPB are reported in detail by Flentje et al. (2010) and are briefly summarized here. There is no significant increase of PNC for particle sizes from $300 \mathrm{~nm}$ to $500 \mathrm{~nm}$ measured with an optical particle counter (OPC), Grimm, Ainring, Germany. The number of larger particles $(300-1000 \mathrm{~nm}, 300-2000 \mathrm{~nm}, 300-4000 \mathrm{~nm}, 300$ $5000 \mathrm{~nm}$ and $300-7500 \mathrm{~nm}$ ) however increased significantly on 17 April. Local precipitation on 18 April and 20 April repeatedly washed out particles (see Sect. 4.4.4 for analyses of wet deposition). The $\mathrm{SO}_{2}$ concentrations at HPB were correspondingly high from 19 April to 21 April and peak values were about $25 \%$ above the 99-percentile values from 2000 to 2007.

Comparison of particle samples recorded with and without TDs at SSL and ZSF between 14:00 and 16:00 on 17 April showed a considerable fraction of particles which consisted of evaporating material. This indicates the presence of evaporable secondary aerosol which was initially not of volcanic origin but may have been formed in the volcanic plume from $\mathrm{SO}_{2}$. At the same time, elevated PNC were also found at the urban background site AUHS. Because of the much higher anthropogenic regional and urban background at this site, this maximum cannot be attributed to the volcanic plume (no enhanced $\mathrm{SO}_{2}$ concentrations, see Sect. 4.4.1). Note also that the increase of ultrafine PNC at HPB was much less pronounced in comparison with SSL or ZSF (see Sect. 4.4.3 too).

\subsection{Measurements of trace elements to estimate $\mathbf{P M}_{10}$ mass enhancement caused by the volcanic plume}

The composition of daily $\mathrm{PM}_{10}$ samples collected by the LÜB was analysed from 18 April to 20 April. The average increase of $\mathrm{PM}_{10}$ concentrations at all LÜB measurement sites $(n=45)$ was $14 \mu \mathrm{g} \mathrm{m}^{-3}$ from 18 April to 19 April and $8 \mu \mathrm{g} \mathrm{m}^{-3}$ from 19 April to 20 April. On 19 April, the threshold value for the daily average of $\mathrm{PM}_{10}$ concentrations $\left(50 \mu \mathrm{g} \mathrm{m}^{-3}\right)$ was exceeded at 5 monitoring sites (two in München (MÜLA and Stachus), two in Augsburg (Königsplatz and AUBÜ) and one in Kempten (about $100 \mathrm{~km}$ south-west from München). On 20 April, exceedances of the threshold values were reported for 10 monitoring sites, mainly in München (all 5 sites) and in Augsburg (all 3 sites). Also, Ansbach (about $40 \mathrm{~km}$ south-west from Nürnberg) and Nürnberg (both located in northern part of the LÜB) reported daily average $\mathrm{PM}_{10}$ concentrations higher than the threshold value.

The contribution of volcanic plume to the $\mathrm{PM}_{10}$ levels in the northern Alpine area was investigated by the analyses of the elemental composition of $\mathrm{PM}_{10}$ samples. A similar method was applied by the environmental agency of BadenWürttemberg (LUBW, located west of the LÜB) described in Krabbe et al. (2010) who used aluminium (Al), iron ( $\mathrm{Fe})$, calcium $(\mathrm{Ca})$, potassium $(\mathrm{K})$, magnesium $(\mathrm{Mg})$, $\operatorname{sodium}(\mathrm{Na})$, titanium $(\mathrm{Ti})$, barium $(\mathrm{Ba})$, manganese $(\mathrm{Mn})$ and the rare Earth 


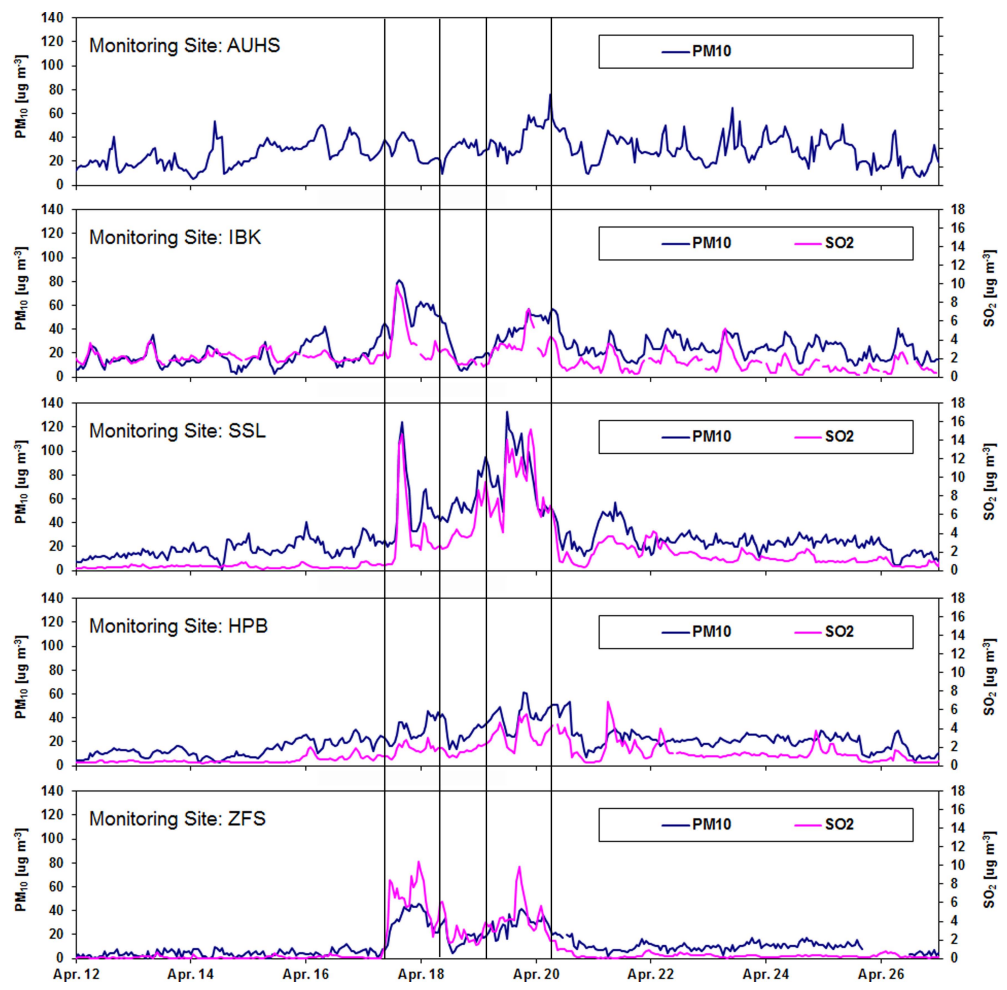

Fig. 6. Time series of $\mathrm{PM}_{10}$ and $\mathrm{SO}_{2}$ (hourly mean data) concentrations at the five core measurement sites Augsburg (AUHS), Innsbruck (IBK), Schauinsland (SSL), Hohenpeissenberg (HPB) and Zugspitze/Schneefernerhaus (ZSF) in the time period from 12 April to 27 April. The two main entrainment events of the volcanic plume are shaded. Note that $\mathrm{PM}_{10}$ and $\mathrm{SO}_{2}$ show a strongly correlated evolution at all measurement sites.

metals scandium $(\mathrm{Sc})$, vanadium $(\mathrm{V})$, yttrium $(\mathrm{Y})$ and zirconium $(\mathrm{Zr})$ for the detection of volcanic plume influences at a background site in the Black Forest (about $14 \mathrm{~km}$ south of SSL, see Fig. 1). At this background site, a significant increase in the concentrations of all these elements was observed. Also, significantly increased concentrations of most elements named above on 19 April and 20 April were found. For example, in Fig. 8 the concentration of Ti at these sites during the time period from 14 April to 23 April is shown.

To estimate the contribution of volcanic plume material to $\mathrm{PM}_{10}$, it is basically possible to use elements with a significant increase in $\mathrm{PM}_{10}$ and a high enrichment factor found in the ash samples. Some elements like Fe and Mn show however rather high background values due to the impact of anthropogenic sources (e.g. abrasion of braking pads, industry etc.) and are therefore less suitable for this purpose. The elemental composition of Eyjafjallajökull ashes have been published on the website of the Institute of Earth Sciences of the University of Iceland (http://www.earthice.hi.is/page/ IES-EY-CEMCOM). Compared to the average composition of the Earth crustal material (Binder, 1999), the elements Mn, phosphorus (P), Sc, strontium ( $\mathrm{Sr}$ ), Ti, $\mathrm{Y}$ and $\mathrm{Zr}$ are enriched by a factor higher than 2 (see Table 2). The enrichment factor is the ratio of average concentration in Eyjafjallajökull ash and Earth crust. The exception is P, which was not quan- tified in our samples. Therefore, apart from $\mathrm{P}$ these highly enriched elements were used to estimate the impact of the volcanic plume on $\mathrm{PM}_{10}$ concentrations.

Figure 9 shows the surplus of Ti, Mn, Sr, Y, and Zr concentrations in ambient $\mathrm{PM}_{10}$ on 19 April and 20 April, respectively, over the average concentration measured during the reference period from 14 to 16,22 and 23 April at the five selected LÜB stations. The coincidental increase of the concentrations of Ti, Mn, Sr, Y and Zr on 19 April and 20 April is evidently the impact of the volcanic plume on $\mathrm{PM}_{10}$ concentrations. A lower impact of volcanic plume compounds was found at the background site in eastern Bavaria (TBAL) and in the northern Alpine Inn valley (OBIA) while highest values occurred in the Augsburg-München area. This spatial distribution corresponds with the spatial distribution of $\mathrm{PM}_{10}$ concentrations (see Fig. 5: the highest concentrations of $\mathrm{PM}_{10}$ were measured in the latter area, too). Unfortunately, the SSL and ZSF $\mathrm{PM}_{10}$ samples could not be analyzed in the same way as the LÜB samples because different filters were used in those samplers (glass fibre filters instead of quartz fibre filters in the LÜB). But Schleicher et al. (2011) showed by chemical fingerprint analyses combined with multivariate statistical method discrimination that at least $40 \%$ of the analyzed particles between 2.5 and $10 \mu \mathrm{m}$ size at the remote sampling sites in the Black Forest area 


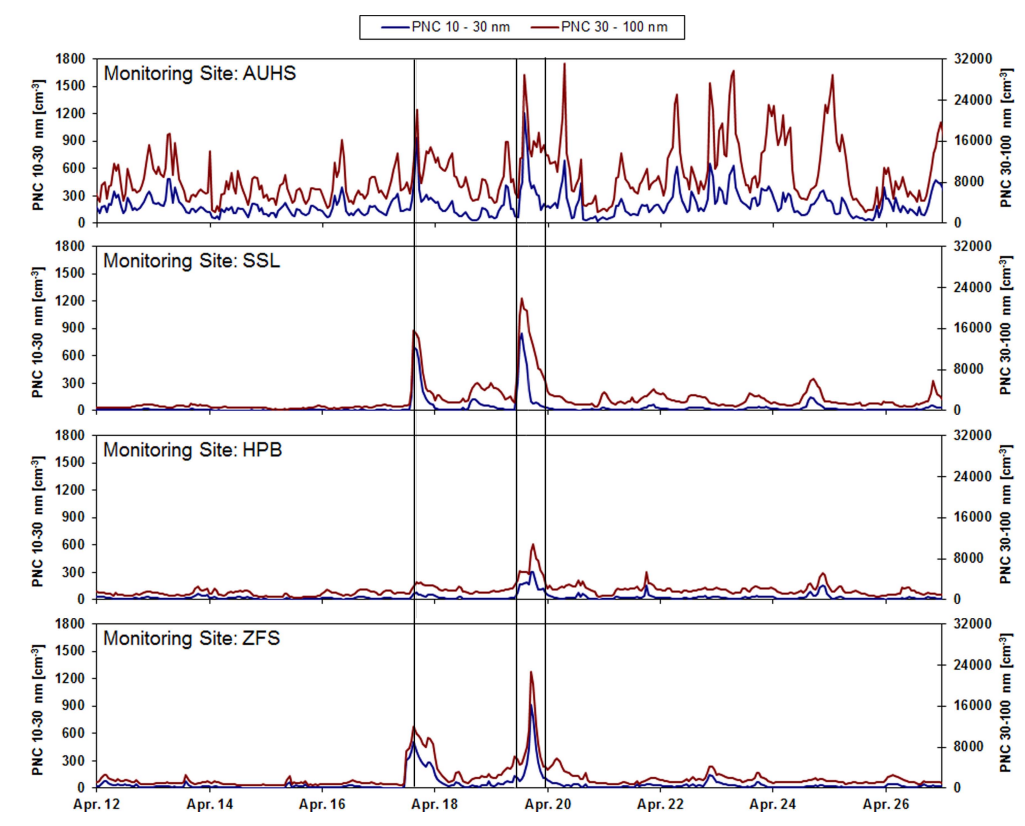

Fig. 7. Time series of ultrafine particle number concentration (PNC, hourly mean data) in two different size ranges at Augsburg (AUHS), Schauinsland (SSL), Hohenpeissenberg (HPB) and Zugspitze/Schneefernerhaus (ZSF) from 12 April to 27 April. The first maximum signal peak is on 17 April between 15:00 and 16:00 at SSL and ZSF (indicated by one vertical line) and the second one on 19 April between 12:00 and 13:00 at SSL and between 16:00 and 18:00 at HPB and ZSF (indicated by corresponding vertical lines). At AUHS, the maximum cannot be clearly attributed to volcanic origin because of the much higher anthropogenic regional and urban contributions to the concentration levels at this site.

Table 2. Part of elemental composition of Eyjafjallajökull volcanic ashes (Institute of Earth Sciences of the University of Iceland (http: //www.earthice.hi.is/page/IES-EY-CEMCOM)) and Earth crust (Binder, 1999). The enrichment factor is the ratio of average concentration in Eyjafjallajökull ash and Earth crust. Only elements with enrichment factor $>2$ were used for estimation of volcanic plume contribution to ambient PM and are given here. The conversion factor is the reciprocal value of the average concentration of the respective element in Eyjafjallajökull ash.

\begin{tabular}{llrrrrr}
\hline element & $\begin{array}{l}\text { percentage } \\
\text { or ppm }\end{array}$ & \multicolumn{2}{c}{$\begin{array}{c}\text { concentration and } \\
\text { uncertainty }\end{array}$} & $\begin{array}{l}\text { concentration } \\
\text { in Earth crust }\end{array}$ & $\begin{array}{r}\text { enrichment } \\
\text { factor }\end{array}$ & $\begin{array}{r}\text { conversion } \\
\text { factor }\end{array}$ \\
\hline $\mathrm{Ti}$ & $\%$ & 0.95 & \pm 0.15 & 0.41 & 2.6 & 105 \\
$\mathrm{Mn}$ & $\%$ & 0.19 & \pm 0.01 & 0.09 & 2.2 & 540 \\
$\mathrm{Sc}$ & $\mathrm{ppm}$ & 15 & \pm 1 & 5.1 & 3.1 & 68000 \\
$\mathrm{Y}$ & $\mathrm{ppm}$ & 67 & \pm 3 & 26 & 2.7 & 15000 \\
$\mathrm{Sr}$ & $\mathrm{ppm}$ & 300 & \pm 25 & 140 & 2.4 & 33000 \\
$\mathrm{Zr}$ & $\mathrm{ppm}$ & 503 & \pm 27 & 210 & 2.3 & 2000 \\
\hline
\end{tabular}

(including SSL) and about $25 \%$ in the city of Freiburg during the week 16-23 April were clearly of volcanic origin. Details about the spatial and temporal PM $_{10}$ patterns across Austria are given in the Supplement.

Using the known concentrations of Ti, Mn, Sr, Y and Zr of the Eyjafjallajökull ash, the contribution of volcanic plume to ambient $\mathrm{PM}_{10}$ samples has been estimated by multiplying the surplus in concentration (Fig. 9) with corresponding conversion factors (see Table 2). On this basis, the impact of the volcanic plume to $\mathrm{PM}_{10}$ was $12 \pm 5 \mu \mathrm{g} \mathrm{m}^{-3}$ on 19 April and $17 \pm 7 \mu \mathrm{g} \mathrm{m}^{-3}$ on 20 April $(25 \pm 10 \%$ on both days) at AUBÜ. The corresponding values for ADRO are $8 \pm 3 \mu \mathrm{g} \mathrm{m}^{-3}$ on 19 April and $10 \pm 4 \mu \mathrm{g} \mathrm{m}^{-3}$ on 20 April ( $26 \pm 10 \%$ on both days). The high variability of these values is reflecting the uncertainty in the basic data (composition of volcanic ash and $\mathrm{PM}_{10}$ sample analysis), and the unquantifiable impact of sources other than the volcanic plume on elevated element concentrations. These values of volcanic ash related $\mathrm{PM}_{10}$ are a little bit lower than those for Mulhouse with 20 to $38 \mu \mathrm{g} \mathrm{m}^{-3}$ on average over 18 and 19 April reported by Colette et al. (2011) and for Basel with up to $45 \mu \mathrm{g} \mathrm{m}^{-3}$ on 18 April by Bukowiecki et al. (2011). 


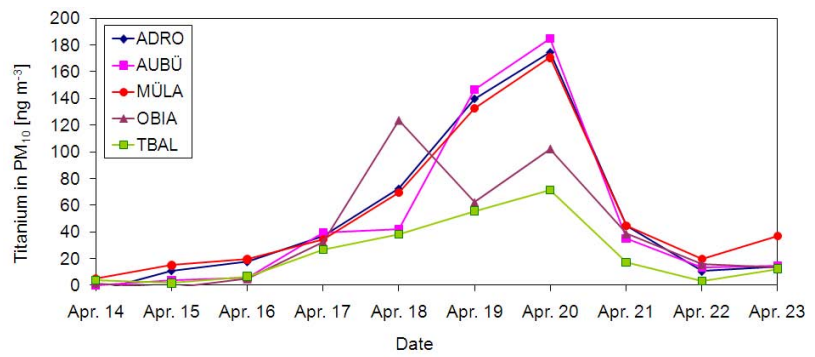

Fig. 8. Concentrations of Titanium in ambient $\mathrm{PM}_{10}$ samples at five LÜB sites (see Fig. 1 also: Andechs/Rothenfeld (ADRO), Augsburg (Bürgermeister-Ulrich-Strasse) (AUBÜ), München (Landshuter Allee) (MÜLA), Oberaudorf (Inn valley motorway) (OBIA), Tiefenbach/Altenschneeberg (TBAL)) from 14 April to 23 April. This variation corresponds with the spatial distribution of $\mathrm{PM}_{10}$ concentrations on 19 April and 20 April as shown in Fig. 5.

On the other hand, the estimation of the volcanic plume contribution is supported by the fact that the fraction of both ammonium and nitrate in the $\mathrm{PM}_{10}$ samples, which are also indicators for secondary aerosol, were substantially reduced during the volcanic plume events. Primary aerosol dominated those $\mathrm{PM}_{10}$ samples which are usually dominated by secondary aerosol. Further, only small changes of sulphate are observed, because part of it has probably been of volcanic origin.

\subsection{Additional measurements at the core monitoring sites}

\subsubsection{Evidence of volcanic plume influences in Augsburg (AUHS)}

Within the $\mathrm{PM}_{10}$ record at AUHS (Fig. 6), peak concentrations were at least partially masked by the enhanced anthropogenic background. However, consideration of additional volcanic fingerprint data as described in Sect. 4.3 allows for an enhanced interpretation of the observed $\mathrm{PM}_{10}$ time series and reveals a volcanic influence, too.

Also HYSPLIT backward trajectories (Draxler and Rolph, 2011) for AUHS were used for the days from 17 April to 20 April. These analyses confirm the former findings (Sect. 4.1) regarding the motion of the volcanic plume across Germany. At all levels, the trajectories consistently show an air flow from north-westerly directions on 17 April which caused effective transport of the volcanic plume to Southern Germany during this time. On 17 April and 18 April, the transport to Augsburg was from easterly directions but on 19 April and 20 April it turned to westerly directions, which is in line with the satellite observations and the surface wind analysis (see Figs. 3 and 4).

Ceilometer backscatter intensities at AUHS showed a layer of strongly enhanced backscatter above the PBL only on 17 April until 13:00 (see Fig. 10). From 02:00 until

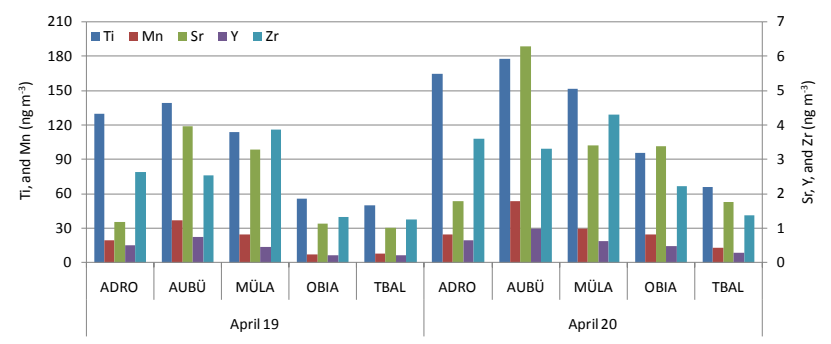

Fig. 9. Surplus in concentration of the elements Ti, Mn, Sr, $\mathrm{Y}$, and $\mathrm{Zr}$ in ambient $\mathrm{PM}_{10}$ on 19 April and 20 April over the average concentration in the reference period $(14,15$, 16, 22 and 23 April) at five LÜB sites (see Fig. 1 also: Andechs/Rothenfeld (ADRO), Augsburg (Bürgermeister-UlrichStrasse) (AUBÜ), München (Landshuter Allee) (MÜLA), Oberaudorf (Inn valley motorway) (OBIA), Tiefenbach/Altenschneeberg (TBAL)).

13:00, the volcanic plume subsided and was finally mixed into the PBL where its clear signature finally disappeared. From 17:00 until mid-night, a structured layer in the upper part of the PBL became visible and is interpreted as a remnant of the formerly confined plume layer above a stable lower atmosphere. The ceilometer observations further indicate that there was a defined upper boundary of the PBL and the lower atmosphere was well mixed on 17 April from 13:00 until 17:00 up to about $1500 \mathrm{~m}$ a.g.l., i.e. the vertical extension of the PBL was relatively large. Entrainment of volcanic material into the PBL must be assumed in this phase, but a corresponding signal on the near-surface air composition at Augsburg was not detectable due to strong dilution and high background concentrations. On 19 April, the situation became different: Due to convection, the distinct separation of the PBL and the free troposphere above disappeared. Flentje et al. (2010) reported thin plume layers all day on 19 April which could partly reach AUHS due to good vertical mixing and advection. During the following night, a stable near-surface layer and a residual second layer (Fig. 10) were formed. Such meteorological conditions favoured the enrichment of air pollutants at near-surface level, as seen during the night 19/20 April in Figs. 5 and 6.

Time series of further parameters of PM (size ranges 0.1$1 \mu \mathrm{m}, 1-2.5 \mu \mathrm{m}$ and $2.5-10 \mu \mathrm{m}$ ) and sulphate concentrations measured in $\mathrm{PM}_{2.5}$ at AUHS from 17 April to 20 April are shown in Fig. 11a and b. Beginning on 19 April, 18:00, an increased PM mass concentration was observed. This could be seen as a consequence of the meteorological conditions described above and associated downward mixing and horizontal replacement, i.e. the exchange of air mass which is loaded with volcanic material. The mass concentration is essentially pronounced for particle sizes larger than $1 \mu \mathrm{m}$ (Fig. 11a). The mass concentration of smaller particles (0.1$1 \mu \mathrm{m})$ was not strongly increased compared to other days, i.e. on 17 April. The mass concentration increase of the particles 

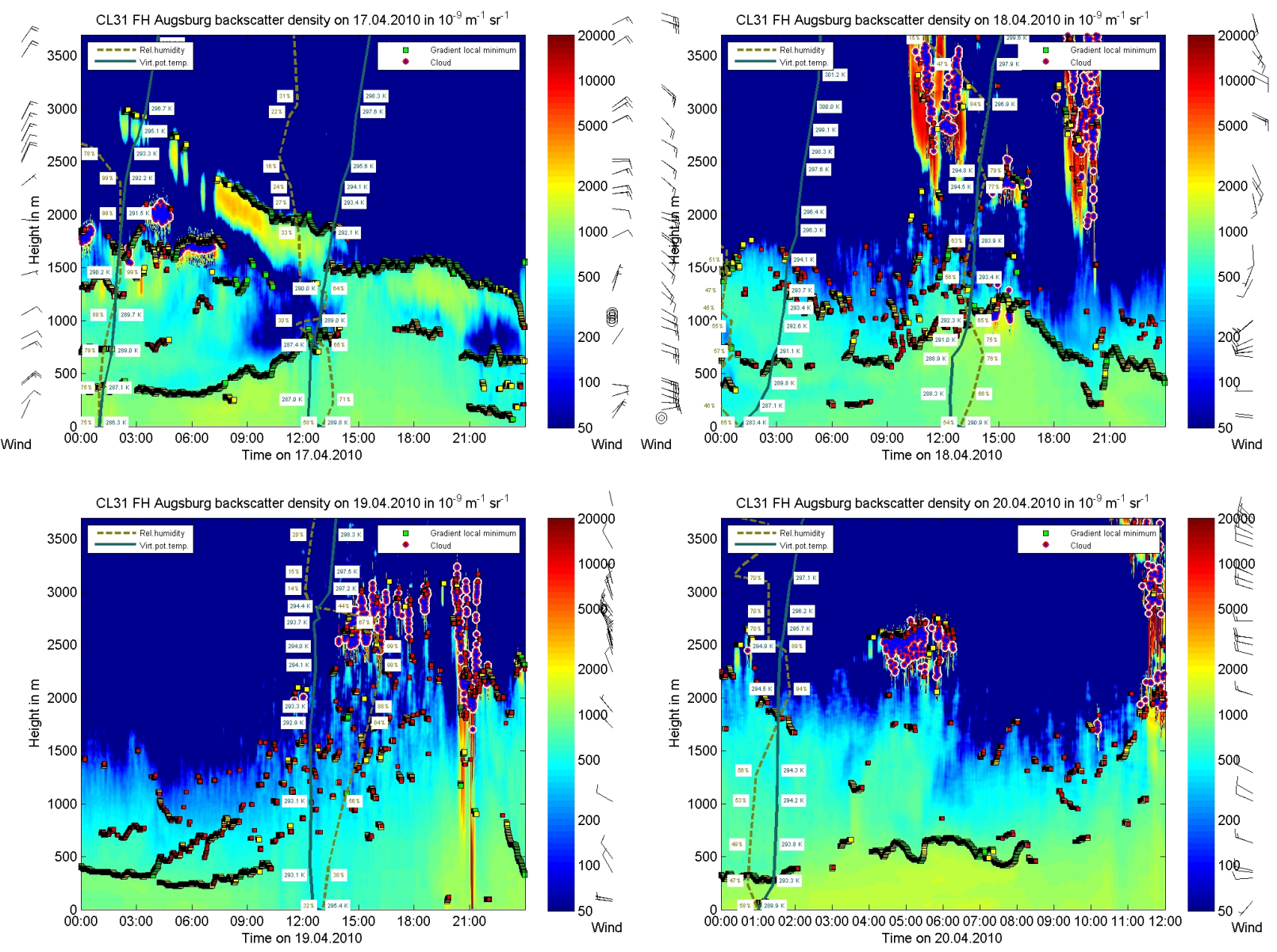

Fig. 10. Observation results on 17 April (upper panel left), 18 April (upper panel right), 19 April (lower panel left) and 20 April from 00:00 to 12:00 (lower panel right) for ceilometer backscatter densities (colour coded) at Augsburg (AUHS). The computed height of the mixing layer is indicated by black dots in the lower panels. Additionally the results of the observations of the radiosonde from Oberschleissheim near München at noon and midnight are shown: height profiles of wind, relative humidity and virtual potential temperature (values at the profiles).

in the size range $1-2.5 \mu \mathrm{m}$ is consistent with the increase of sulphate concentration in $\mathrm{PM}_{2.5}$ (Fig. 11b). It is also in line with the only very small PNC increase of PM with sizes from 100 to $800 \mathrm{~nm}$ (see Sect. 4.2).

It is striking that an increased concentration of sulphate in $\mathrm{PM}_{2.5}$ occurred without a major $\mathrm{SO}_{2}$ peak during the volcanic plume episode in Augsburg (see Sect. 4.2). It is also corroborated by a small increase of accumulation mode particles. There can also be coating to the surface of existing fine and coarse particles with UFP $\left(\mathrm{H}_{2} \mathrm{SO}_{4}\right)$ as discussed by Schumann et al. (2011) and Lettino et al. (2011). Furthermore, as the travel time is about 3 days and $\mathrm{H}_{2} \mathrm{SO}_{4}$ particles grow at about 6-7 $\mathrm{nm} \mathrm{h}^{-1}$ (Hamad et al., 2010) it seems possible that $\mathrm{H}_{2} \mathrm{SO}_{4}$ is a compound of particles with sizes between 1 and $2.5 \mu \mathrm{m}$ as is typical for sulphate (Fig. 11). Further dilution during transport down to the surface inhibited significant increases of $\mathrm{SO}_{2}$ concentration in the urban air in Augsburg, whereas such an increase was observed at core monitoring sites at higher elevations. It can be concluded that $\mathrm{H}_{2} \mathrm{SO}_{4}$ in UFP is formed much faster than the sulphate in accumulation mode particles.

The increased content of sulphate in $\mathrm{PM}_{2.5}$ correlates with the first maximum of particle mass concentration $\left(\mathrm{PM}_{0.1-1}\right.$, $\mathrm{PM}_{1-2.5}$ and $\mathrm{PM}_{2.5-10}$ ) on 19 April, 23:00. This indicates that this increase of particle mass is associated with the influence of the volcanic plume. A source apportionment on the basis of PSD analyses for Augsburg is published by Pitz et al. (2011) which is used to separate volcanic ash and dust from other sources. It provides a contribution of $61 \%$ $\left(48 \mu \mathrm{g} \mathrm{m}^{-3}\right)$ by long range transported dust (mass peak between 1 and $4 \mu \mathrm{m}$ with a maximum at $2 \mu \mathrm{m}$ ) i.e. mainly volcanic material to the average $\mathrm{PM}_{10}$ mass concentration on 19 April, 23:00. 

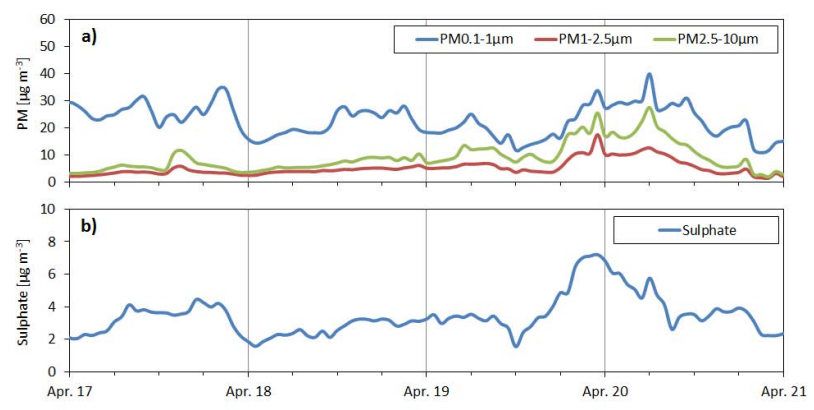

Date

Fig. 11. Time series of additional parameters (hourly mean data) measured at Augsburg (AUHS) (17 April to 20 April) for (a) particle mass concentrations $\left(\mathrm{PM}_{0.1-1}, \mathrm{PM}_{1-2.5}\right.$ and $\left.\mathrm{PM}_{2.5-10}\right)$ and (b) sulphate mass concentration in $\mathrm{PM}_{2.5}$. A volcanic plume influence is visible from the afternoon of 19 April until the morning of 20 April by significant increased concentrations of sulphate and coarse particles $\left(\mathrm{PM}_{1-2.5}\right.$ and $\left.\mathrm{PM}_{2.5-10}\right)$.

\subsubsection{Vertical profiles of parameters from ultralight aircraft flight}

A flight by ultralight aircraft in the afternoon of 19 April coincided with the arrival of a volcanic plume in the area. The ascent was performed in an aged air mass typical for a high pressure episode in the North Alpine forelands. The aircraft climbed above the shallow cumulus cloud layer present between about 2800 and $3200 \mathrm{~m}$ a.g.l. (for more details, see Emeis et al., 2011) and stayed there for about $15 \mathrm{~min}$. In the following descent, the characteristic features of the air mass significantly changed. The average ozone concentration in the lower $3000 \mathrm{~m}$ decreased from 140 to $95 \mu \mathrm{g} \mathrm{m}^{-3}$ and the height of the maximum in the dewpoint profile indicating the upper rim of the mixing layer declined from about $1500 \mathrm{~m}$ down to $800 \mathrm{~m}$ a.g.l. In both profiles, the dewpoint above this local maximum steadily decreased with height, a feature which in stagnant high pressure conditions is normally associated with cumulus clouds with a by far lower cloud base close to the maximum dewpoint. However, clouds were present at a greater height only. The change in the profiles is thus more likely due to a replacement of the air mass in the area beginning at about $3000 \mathrm{~m}$ a.g.l. and gradually progressing towards the ground where the new air mass was detected about one hour after the landing of the aircraft. Fine PNC and PSD did not change significantly between the aged air mass during the ascent and the volcanic plume influenced air mass of the descent but the optical properties were different. The spectral absorption in the UV was nearly completely suppressed while the absorption at $880 \mathrm{~nm}$ was comparable high in both profiles (see also Emeis et al., 2011). Concurrent with the reduction in UV absorption, a strong increase in the extinction in the near infrared was observed, a clear indication of a different chemical composition of the air mass.

\subsubsection{Fine particles at Zugspitze/Schneefernerhaus (ZSF)}

To further characterize the ZSF time series, the total PNC measured by a CPC was analyzed. Especially at the beginning of the event with high PNC of very small aerosol particles (10-30 nm size range, see Fig. 7) we observed a considerably higher signal of the water-based CPC. It is therefore likely that particles measured at that time were mainly water soluble, being in line with the aerosol measurements using the TD channel. A possible source of such water-soluble aerosols would be the high $\mathrm{SO}_{2}$ content which, after chemical transformation, leads to sulphate-rich, water-soluble particles (Hamed et al., 2010).

The scattering properties of aerosols were recorded by a three-wavelength nephelometer $(450 \mathrm{~nm}, 550 \mathrm{~nm}, 700 \mathrm{~nm})$. The retrieved Angström exponents were mostly inverse to $\mathrm{SO}_{2}$ concentrations indicating that parallel to high $\mathrm{SO}_{2}$ concentrations high concentrations of particles larger than $1 \mu \mathrm{m}$ size were transported to ZSF. Diverging from this finding, decreased aerosol scattering was already observed from 16 April, 12:00 onwards while the $\mathrm{SO}_{2}$ concentration did not increase until 17 April, 11:00. Precipitation starting on 18 April, 15:00 and on 20 April, 17:00 and 21:00, was likely responsible for increasing Ångström exponents, presumably due to scavenging of coarse aerosol particles. The $\mathrm{SO}_{2}$ concentration levels however were not subject to reduction by precipitation because of the very low amount $(0.04-0.07 \mathrm{~mm}$ on 18 April).

The entrainment of the volcanic plume into the PBL proceeded from East to West due to predominant south-easterly winds for $24 \mathrm{~h}$ (see Figs. 3 and 4). After 18 April, 03:00, the wind changed first to western, then to northern direction and again to westerly directions. From 18 April, 08:00 onwards, easterly winds again dominated.

\subsubsection{Composition of wet deposition at Hohenpeissenberg (HPB) and at Schauinsland (SSL)}

On 18 April from about 12:00 to 14:00 and on 20 April from about 13:50 to $15: 10$ and with some breaks from 19:10 onwards, it was slightly raining at HPB. Samples of these precipitation events were analysed for water soluble ions (nitrate $\left(\mathrm{NO}_{3}-\mathrm{N}\right)$, sulphate $\left(\mathrm{SO}_{4}-\mathrm{S}\right)$, ammonium $\left(\mathrm{NH}_{4}-\mathrm{N}\right)$ and hydrogen ion $\left(\mathrm{H}^{+}\right)$), elements (chlorine $(\mathrm{Cl}), \mathrm{Na}, \mathrm{K}, \mathrm{Mg}$ and $\mathrm{Ca}$ ), acidity or basicity $(\mathrm{pH})$ and conductivity. Table 3 shows the results for deposition (not $\mathrm{pH}$ ). For reference, the table also includes the highest, mean and lowest depositions observed at HPB in April, during the ten preceding years.

Due to the small precipitation amounts $(1.7 \mathrm{~mm}$ on 18 April and $2.8 \mathrm{~mm}$ on 20 April), concentrations were generally high. Conductivity and $\mathrm{H}^{+}$concentration on 18 April were the second highest of all April precipitation events from 2000 to 2009 , the sulphate concentration on that day ranked 
Table 3. Ion depositions and conductivities in precipitation (wet deposition) at Hohenpeissenberg (HPB) and at Schauinsland (SSL).

\begin{tabular}{|c|c|c|c|c|c|c|c|c|c|c|}
\hline \multicolumn{11}{|c|}{ Deposition } \\
\hline date & $\begin{array}{r}\text { cond. } \\
\mu \mathrm{S} \mathrm{cm}^{-1}\end{array}$ & $\begin{array}{r}\mathrm{H}^{+} \\
\mathrm{mg} \mathrm{m}^{-2}\end{array}$ & $\mathrm{mg} \mathrm{m}^{-2}$ & $\begin{array}{r}\mathrm{NO}_{3}-\mathrm{N} \\
\mathrm{mg} \mathrm{m}^{-2}\end{array}$ & $\begin{array}{r}\mathrm{SO}_{4}-\mathrm{S} \\
\mathrm{mg} \mathrm{m}^{-2}\end{array}$ & $\begin{array}{r}\mathrm{Na} \\
\mathrm{mg} \mathrm{m}^{-2}\end{array}$ & $\begin{array}{r}\mathrm{NH}_{4}-\mathrm{N} \\
\mathrm{mg} \mathrm{m}^{-2}\end{array}$ & $\begin{array}{r}\mathrm{K} \\
\mathrm{mg} \mathrm{m}^{-2}\end{array}$ & $\begin{array}{r}\mathrm{Mg} \\
\mathrm{mg} \mathrm{m}^{-2}\end{array}$ & $\begin{array}{r}\mathrm{Ca} \\
\mathrm{mg} \mathrm{m}^{-2}\end{array}$ \\
\hline \multicolumn{11}{|l|}{ HPB } \\
\hline April 2000-2009 max & 85.8 & 0.653 & 12.7 & 27.0 & 14.0 & 6.3 & 44.2 & 1.4 & 1.3 & 7.2 \\
\hline April 2000-2009 mean & 21.1 & 0.047 & 1.0 & 3.9 & 2.4 & 0.5 & 5.4 & 0.2 & 0.2 & 1.2 \\
\hline April 2000-2009 min & 5.1 & 0.0001 & 0.008 & 0.060 & 0.026 & 0.002 & 0.098 & 0.016 & 0.005 & 0.012 \\
\hline 18 April 2010 & 66.5 & 0.073 & 0.3 & 3.9 & 4.5 & 0.3 & 7.3 & 0.2 & 0.2 & 1.9 \\
\hline 20 April 2010 & 32.0 & 0.004 & 0.7 & 4.7 & 3.1 & 0.3 & 7.8 & 0.2 & 0.2 & 1.6 \\
\hline \multicolumn{11}{|l|}{ SSL } \\
\hline April 2008-2009 max & 42.0 & 0.60 & 5.5 & 3.8 & 7.9 & 3.8 & 20.5 & 1.4 & 1.2 & 5.0 \\
\hline April 2008-2009 mean & 14.3 & 0.11 & 1.2 & 0.8 & 1.4 & 0.9 & 3.8 & 0.4 & 0.2 & 1.6 \\
\hline April 2008-2009 min & 2.00 & 0.00044 & 0.18 & 0.05 & 0.05 & 0.104 & 0.15 & 0.04 & 0.03 & 0.16 \\
\hline 20 April 2010 & 87.9 & 0.00021 & 0.7 & 5.3 & 3.7 & 0.8 & 7.7 & 0.9 & 0.2 & 1.6 \\
\hline
\end{tabular}

in third place. The deposition data do not exceed the maximum values measured in April during the ten preceding years. On 18 April, deposition of $\mathrm{H}^{+}$and sulphate was unusually high, but both components were similarly high during the week before the eruption. These high depositions can therefore largely be attributed to the advection of polluted continental air in the PBL rather than to the volcanic plume on that day. On 20 April, the precipitation event was at the end of the volcanic influence upon the PBL. The same results were found in May, when additional volcanic plumes were detected through high $\mathrm{SO}_{2}$ concentrations at ZSF. In summary, the wet deposition analysis results from HPB do not provide information about the volcanic influence on the air composition.

On 20 April at SSL only a minor amount of $0.4 \mathrm{~mm}$ precipitation took effect in deposition. The depositions for $\mathrm{SO}_{4}-$ $\mathrm{S}, \mathrm{NO}_{3}-\mathrm{N}, \mathrm{NH}_{4}-\mathrm{N}$ as also for $\mathrm{H}^{+}$and $\mathrm{Cl}$ show quite similar values compared to HPB at that day (see Table 3). Although conductivity on 20 April showed the highest value compared to April 2008 and April 2009 it is not evident that the measured depositions result from the volcanic plume influence. Thus the higher depositions at SSL can be attributable to the existing advection of polluted continental air in the PBL as at HPB.

\section{Synthesis and discussion}

\subsection{Volcanic influences on air quality}

Entrainment of volcanic plume material into the lower atmosphere was evident beginning from about the noon of 17 April due to the observed increase of $\mathrm{PM}_{10}$ and $\mathrm{SO}_{2}$ concentrations at the elevated observation sites $\mathrm{ZSF}$ (2670 m a.s.1.) and SSL (1200 ma.s.1.) as well as at IBK (570 ma.s.1.). As the PBL was well mixed on 17 April (Fig. 10), the volcanic plume reached the lower atmosphere in our study area in only a diluted form. A second event ar- rived during the night from 17 April to 18 April with traces of additionally enhanced concentrations of $\mathrm{PM}_{10}$ and $\mathrm{SO}_{2}$ as measured at ZSF and IBK. The latter site is fairly representative for the conditions in the north-west regions of Austria, while pronounced spatial gradients and time delays were observed towards the South and East reflecting specific topographic and meteorological effects (see Supplement). In Southern Germany, the associated meteorological conditions are characterised by a stable PBL up to $1500 \mathrm{~m}$ a.g.l., thus hampering effective down-mixing of the volcanic plume material to the surface.

During the afternoon of 19 April, another increase of $\mathrm{PM}_{10}$ and $\mathrm{SO}_{2}$ concentrations was measured at nearly all stations in Southern Germany and in the Innsbruck area with peaks around mid-night and a subsequent concentration decrease until the noon of 20 April. During this event, the meteorological conditions were more comfortable for downward mixing of the volcanic plume. The PBL extended up to about $2000 \mathrm{~m}$ a.g.l. during that time due to convective conditions favouring an entrainment of volcanic plume material into the PBL. The subsequent formation of a stable PBL with limited mixing near the ground during the evening of 19 April led to the additional accumulation of locally emitted particles.

Advection was also important. Between the second and third event the synoptic situation became different and the air flow changed from an easterly up to a westerly direction. That means that in the afternoon of 19 April, an exchange of air masses occurred in the northern Alpine region.

The enhanced $\mathrm{PM}_{10}$ values on 19/20 April could just as well have been caused by anthropogenic sources. However, chemical analyses of $\mathrm{PM}_{10}$ samples revealed a very unusual elemental pattern with an increase in the concentration of elements like $\mathrm{Ti}, \mathrm{Zr}$ and $\mathrm{Y}$ by a factor of more than 10 at five LÜB monitoring stations. This is different to Saharan dust events which are composed of the Earth crust elements too (see Table 2). During such events, enriched concentrations of the primarily oxides of silicon $(\mathrm{Si}), \mathrm{Fe}$ and $\mathrm{Al}$ from 
24 March to 25 March 2007 (Vanderstraeten et al., 2008) or $\mathrm{Fe}, \mathrm{Al}, \mathrm{Ca}, \mathrm{Ni}$ and As from 27 May to 1 June 2008 (Bruckmann et al., 2008) were found. But enhanced Ti concentrations as observed during the Eyjafjallajökull volcano event were never seen in the long-term $\mathrm{PM}_{10}$ elemental analyses. A study for France by Colette et al. (2010) found the similar conclusions especially over 18 April and 19 April in Mulhouse. The investigations by Bukowiecki et al. (2011) in Basel provided an average chemical composition of volcanic plume particles very similar to the trachyandesite-like composition of rock samples collected near the volcano. Rossini et al. (2011) reported the analyses from atmospheric bulk deposition fluxes of total suspended particles (TSP) in Rimini, Italy, where sulphate, $\mathrm{Al}, \mathrm{Ca}, \mathrm{Fe}, \mathrm{Hg}, \mathrm{K}, \mathrm{Li}, \mathrm{P}, \mathrm{Si}$ and Ti reached significantly high values in the period 19 April17 May 2010 which are 3 to 4 times higher than in the period 15 July-11 August 2010. In Southern Italy also (Tito Scalo) Littino et al. (2011) found in daily $\mathrm{PM}_{2.5}$ samples from 20 April 2010 on (maximum 22 April) enhanced Al, $\mathrm{Ca}, \mathrm{Fe}, \mathrm{K}, \mathrm{Mg}, \mathrm{Mn}$, and $\mathrm{Ti}$ concentrations.

Those investigated sites (MÜLA, AUBÜ) where the $\mathrm{PM}_{10}$ daily limit of $50 \mathrm{\mu g} \mathrm{m}^{-3}$ was exceeded due to the volcano plume impact were reported to the European Commission to be caused by natural sources (volcano plume). Consequently, the volcanic plume influenced the near-surface atmosphere and thus the ambient air quality. However, the air pollutant emissions caused by the Eyjafjallajökull volcano eruption were much lower than those estimated for the Laki eruption of 1783-1784. The $\mathrm{PM}_{10}$ and $\mathrm{PM}_{2.5}$ concentrations observed during the Saharan dust event from 27 May to 1 June 2008 at the monitoring stations used here were also higher (see Bruckmann et al., 2008) than during the Eyjafjallajökull volcano event but with different particle composition during both events.

For a second time after the April 2010 event, volcanic plume influences have been observed with a significant signal at ZSF from 18 May, 09:00 to 19 May, 24:00. In contrary to April, in May enhanced $\mathrm{SO}_{2}$ concentrations were observed which exceeded $14 \mu \mathrm{g} \mathrm{m}^{-3}$ on 18 May and $8 \mu \mathrm{g} \mathrm{m}^{-3}$ on 19 May. At the same time, precipitation at HPB was relatively clean and did not show any influence from the volcano. The observed $\mathrm{SO}_{2}$ concentration levels were clearly beyond the concentrations in April 2010. In contrast to the April event, frequent precipitation events and high relative humidity occurred during the May episode, which considerably reduced $\mathrm{PM}_{10}$ concentrations to maximum levels at about $20 \mu \mathrm{g} \mathrm{m}^{-3}$. Such enhanced $\mathrm{SO}_{2}$ together with $\mathrm{PM}_{10}$, $\mathrm{PM}_{2.5}$ and sulphate concentrations were found by Revuelta et al. (2011) at the Iberian Peninsula in May 2010 also. During the May episode, various airports in Italy and again the airport at München were nevertheless again closed for safety reasons. A discussion of further observational results together with modelling results can be found in Emeis et al. (2011), Miffre et al. (2011) and Heinold et al. (2011).

\subsection{Possible health damages caused by air pollution originating from the volcanic plume}

Ambient particulate matter has been a long standing concern to induce short-term as well as long-term health effects (Brunekreef and Holgate, 2002; Craig et al., 2008; Dockery, 2009). The size, shape and density of the particles determine their behaviour in the lung. As the human airways are the major surfaces of interaction, particles of sizes less than $10 \mu \mathrm{m}$ entering the airways and of sizes less than $2.5 \mu \mathrm{m}$ entering the lungs are of primary concern. This indicates that in principle, volcanic plume particles have the potential to affect human health. Indeed, reports from volcano outbreaks have demonstrated respiratory effects in study subject with underlying pulmonary disease (Longo et al., 2010; Gudmundsson, 2011; Shimizi et al., 2007; Naumova et al., 2007). These observations seem highly plausible as high concentrations of particles have been indicated to irritate upper airways (Bascom et al., 1996; Peters et al., 1997; Tong et al., 2010). However, these respiratory disease exacerbations in association with acute volcanic particle exposure occurred at concentrations one to two orders of magnitude higher than in the investigated Eyjafjallajökull event. Analyses of medical surveillance data from the UK did not indicate an access of respiratory disease in association with regionally transported particles from the Eyjafjallajökull outbreak (Elliot et al., 2010).

The data presented in this paper indicates that the transported mass of particles in populated areas was largely in the size range $2.5-10 \mu \mathrm{m}$. The control of anthropogenic particles focuses frequently on $\mathrm{PM}_{2.5}$ (Craig et al., 2008). Consistent associations with cardiovascular diseases have been demonstrated in this lower size range (Brook et al., 2010). The strength of adverse health effects of the coarse mode particles are still being debated (Brunekreef and Forsberg, 2005; Zanobetti and Schwartz, 2009; Tong et al., 2010). Regionally transported volcanic particles will mix with other particles from anthropogenic sources as well as may absorb components from the gas phase.

The transported volcanic plume particles may have potentially high acidity due to interaction with sulphur species. For example, $\mathrm{H}_{2} \mathrm{~S}$ has been implicated as a biologically active species in relation to volcano outbreaks (Hansell and Oppenheimer, 2004). These compounds are expected as gases and/or within UFPs which are reaching the lungs. Epidemiologically, no relevant health effects for the population can be expected for the maximum daily average $\mathrm{PM}_{10}$ concentrations (up to $100 \mu \mathrm{g} \mathrm{m}^{-3}$ ) and regional daily average $\mathrm{PM}_{10}$ concentrations (about $60 \mu^{-3} \mathrm{~m}^{-3}$ ). For comparison, in 2010 the threshold value of $50 \mathrm{\mu g} \mathrm{m}^{-3}$ was exceeded on average on 8 days at rural background stations and on 28 days at traffic stations in Germany (UBA, 2011). Thus, the health relevance of the volcanic episode in the northern Alpine region is expected to be minor. 
Nevertheless, it might be of interest to study the toxicological properties of the volcanic plume compounds after longrange transport. Toxicological investigations are underway to further elucidate the biological activity of particles collected during days with volcanic plume exposure. In conclusion, there seems to be little evidence that the particles associated with the Eyjafjallajökull outbreak have a dramatically increased toxicity. At the same time, it seems not to be warranted to assign to the transported volcanic particles the relatively low toxicity of non-anthropogenic influenced re-suspended dust particles (e.g. mineral dust).

\section{Conclusions}

On 17 April, enhanced $\mathrm{PM}_{10}$ and $\mathrm{SO}_{2}$ concentrations were detected at mountain stations (ZSF and SSL) as well in Innsbruck and other Austrian sites by in situ measurement devices. The air quality monitoring networks in Southern Germany (LÜB and LUBW) and ground-based in situ measurement systems at low elevations observed only a moderate increase of $\mathrm{PM}_{10}$ and $\mathrm{SO}_{2}$ during that time. However, peak concentrations of both $\mathrm{PM}_{10}$ and $\mathrm{SO}_{2}$ were detected by a lot of these stations and in Innsbruck on 19/20 April. On the basis of the chemical analyses of $\mathrm{PM}_{10}$ samples (Ti concentrations in $\mathrm{PM}_{10}$ ), the presence of the volcanic plume in the ambient air on 19/20 April can be shown.

From the beginning of 17 April, the ground-based in situ measurement systems at AUHS as well as of LÜB detected increased PM mass concentrations resulting in a peak in the early morning hours on 20 April which could be assigned to an increase of particles with diameters larger than $1 \mu \mathrm{m}$.

It can be finally concluded that on 19/20 April, the volcanic plume was responsible for several $\mathrm{PM}_{10}$ threshold exceedances, thus being relevant for regional air quality. This event was supported by a specific development in the regional weather situation which otherwise prevented an influence of the volcanic plume on air quality at monitoring stations on 17/18 April.

The particles attributed to the volcanic plume appeared either as UFP with diameters smaller than $100 \mathrm{~nm}$, or primary particles larger than $1 \mu \mathrm{m}$. It is concluded here that the high numbers of UFP at the beginning of the volcanic plume event were caused by photochemical processes acting in the $\mathrm{SO}_{2}$-rich regime of the volcanic plume. This chemical composition is a feature that distinguishes the volcanic plume from Saharan dust. Further, the enhanced concentrations of sulphate measured at AUHS and of $\mathrm{H}_{2} \mathrm{SO}_{4}$ at $\mathrm{HPB}$ on 19/20 April (see Flentje et al., 2010) showed that $\mathrm{SO}_{2}$ is transformed into these compounds during the transport of the volcanic plume. The high acidity of volcanic plume particles is a risk for human health in addition to the $\mathrm{PM}_{10}$ threshold exceedance.

Without further evidence from toxicological studies, we assume that the volcanic plume particles contribute to the overall exposure of the population on 19/20 April and therefore in principal may lead to exacerbation of respiratory and cardiovascular symptoms. However, for Germany the effect, if any, is expected to be minor.

\section{Glossary}

\section{List of acronyms}

\begin{tabular}{|c|c|}
\hline a.g.1. & above ground level \\
\hline a.s.1. & above sea level \\
\hline ADRO & LÜB monitoring site Andechs/Rothenfeld \\
\hline APS & aerodynamic particle sizer \\
\hline AUBÜ & LÜB monitoring site Augsburg (Bürgermeister-Ulrich-Strasse) \\
\hline AUHS & measurement site Augsburg \\
\hline CET & Central European Time \\
\hline $\mathrm{CPC}$ & condensation particle counter \\
\hline DWD & German Meteorological Service, Deutscher Wetterdienst \\
\hline GAW & $\begin{array}{l}\text { Global Atmospheric Watch program of the World Meteorological } \\
\text { Organisation }\end{array}$ \\
\hline HMGU & $\begin{array}{l}\text { Helmholtz Zentrum München, German Research Center for Envi- } \\
\text { ronmental Health }\end{array}$ \\
\hline HPB & $\begin{array}{l}\text { GAW-Global Station Hohenpeissenberg, Meteorological Obser- } \\
\text { vatory }\end{array}$ \\
\hline IBK & UBA-AT monitoring site Innsbruck Zentrum, Fallmerayerstrasse \\
\hline IfT & Leibniz Institute for Tropospheric Research \\
\hline JFJ & central Alpine station Jungfraujoch \\
\hline KIT/IMK-IFU & $\begin{array}{l}\text { Karlsruhe Institute of Technology, Institute for Meteorology and } \\
\text { Climate Research, Atmospheric Environmental Research }\end{array}$ \\
\hline LfU & Bavarian Environment Agency \\
\hline lidar & light detection and ranging \\
\hline LÜB & Bavarian Air Monitoring Network of LfU \\
\hline LUBW & $\begin{array}{l}\text { Air Monitoring Network of the Environmental Agency of Baden- } \\
\text { Württemberg }\end{array}$ \\
\hline MÜLA & LÜB monitoring site München (Landshuter Allee) \\
\hline OBIA & LÜB monitoring site Oberaudorf (Inn valley motorway) \\
\hline $\mathrm{OPC}$ & optical particle counter \\
\hline PBL & planetary boundary layer \\
\hline PM & particulate matter \\
\hline PNC & particle number concentrations \\
\hline PSD & particle number size distributions \\
\hline SMPS & scanning mobility particle sizer \\
\hline SSL & UBA-D station Schauinsland \\
\hline TBAL & LÜB monitoring site Tiefenbach/Altenschneeberg \\
\hline $\mathrm{TD}$ & thermodenuder with $300^{\circ} \mathrm{C}$ \\
\hline TDMPS & twin differential mobility particle sizer \\
\hline TEOM & tapered element oscillating microbalance \\
\hline UBA-AT & $\begin{array}{l}\text { Austrian Federal Environmental Agency (Austrian } \\
\text { Umweltbundesamt) }\end{array}$ \\
\hline UBA-D & $\begin{array}{l}\text { German Federal Environmental Agency (German } \\
\text { Umweltbundesamt) }\end{array}$ \\
\hline UFP & ultrafine particles: particle in the size range $3-100 \mathrm{~nm}$ \\
\hline UTC & coordinated universal time \\
\hline ZSF & GAW-Global Station Zugspitze \\
\hline
\end{tabular}

\section{Supplementary material related to this article is available online at: http://www.atmos-chem-phys.net/11/8555/2011/ acp-11-8555-2011-supplement.pdf.}

Acknowledgements. We like to thank our colleagues C. Jahn, R. Friedl and M. Hoffmann (KIT/IMK-IFU) for effective cooperation during the measurement campaign. Special thanks to J. Kerkmann and K. Holmlund (EUMETSAT) for providing the METEOSAT data that were used in this study. We thank H. Ott from the LfU for providing measurement data and for 
support of this work. Austrian air quality data were provided by A. Krismer (Tyrolean government) and W. Spangl (Austrian Umweltbundesamt, Vienna) which is gratefully acknowledged, too. We thank ZAMG (Vienna) for providing access to ECMWF data. Electromobility measurements in the German Ultrafine Aerosol Network (GUAN) were generously supported by the German Federal Environment Ministry (BMU) grant F\&E 370343200. The authors acknowledge the NOAA Air Resources Laboratory (ARL) for the provision of the HYSPLIT transport and dispersion model and/or READY website (http://www.arl.noaa.gov/ready.php) used in this publication. R. Foreman (KIT/IMK-IFU) is gratefully acknowledged the careful reading of the manuscript for grammatical correctness. We acknowledge support by Deutsche Forschungsgemeinschaft and Open Access Publishing Fund of KIT.

Edited by: K. Schäfer

\section{References}

Bascom, R., Bromberg, P. A., Costa, D. A., Devlin, R., Dockery, D. W., and Frampton, M. W.: Health effects of outdoor air pollution, Amer. J. Respir. Crit. Care Med., 153, 3-50, 1996.

BImSchV: Neununddreißigste Verordnung zur Durchführung des Bundes-Immissionsschutzgesetzes, Verordnung über Luftqualitätsstandards und Emissionshöchstmengen vom 2. August 2010 (BGB1. I S. 1065), Bundesministerium für Umwelt, Naturschutz und Reaktorsicherheit, Berlin, Germany, 2010.

Binder, H. H.: Lexikon der chemischen Elemente, S. Hirzel Verlag, Stuttgart, Germany, ISBN 978-3-7776-0736-8, 870 pp., 1999.

Birmili, W., Berresheim, H., Plass-Dülmer, C., Elste, T., Gilge, S., Wiedensohler, A., and Uhrner, U.: The Hohenpeissenberg aerosol formation experiment (HAFEX): a longterm study including size-resolved aerosol, $\mathrm{H} 2 \mathrm{SO} 4, \mathrm{OH}$, and monoterpenes measurements, Atmos. Chem. Phys., 3, 361-376, doi:10.5194/acp-3-361-2003, 2003.

Birmili, W., Weinhold, K., Nordmann, S., Wiedensohler, A., Spindler, G., Müller, K., Herrmann, H., Gnauk, T., Pitz, M., Cyrys, J., Flentje, H., Nickel, C., Kuhlbusch, T.A.J. Löschau, G., Haase, D., Meinhardt, F., Schwerin, A., Ries, L., and Wirtz, K.: Atmospheric aerosol measurements in the German Ultrafine Aerosol Network (GUAN): Part 1 - soot and particle number size distributions, Gefahrst. Reinh. Luft, 69, 137-145, 2009.

Brand, H. and Krafft, T.: The Icelandic ash cloud and other erupting health threats: what role for syndromic surveillance?, Eur. J. Public Health, 20(4), 367-368, doi:10.1093/eurpub/ckq088, 2010.

Brook, R. D., Rajagopalan, S., Pope III, C.A., Brook, J. R., Bhatnagar, A., and Diez-Roux, A. V.: Particulate matter air pollution and cardiovascular disease: An update to the scientific statement from the American Heart Association, Circulation, 121(21), 2331-2378, 2010.

Bruckmann, P., Birmili, W., Straub, W., Pitz, M., Gladtke, D., Pfeffer, U., Hebbinghaus, H., Wurzler, S., and Olschewski, A.: An outbreak of Saharan dust causing high PM10 levels north of the Alps, Gefahrst. Reinh. Luft, 68(11/12), 490-498, 2008.

Brunekreef, B. and Forsberg, B.: Epidemiological evidence of effects of coarse airborne particles on health, Eur. Respir. J., 26, 2, 309-318, 2005.
Brunekreef, B. and Holgate, S. T.: Air pollution and health, Lancet, 360(9341), 1233-1242, 2002.

Bukowiecki, N., Zieger, P., Weingartner, E., Jurányi, Z., Gysel, M., Neininger, B., Schneider, B., Hueglin, C., Ulrich, A., Wichser, A., Henne, S., Brunner, D., Kaegi, R., Schwikowski, M., Tobler, L., Wienhold, F. G., Engel, I., Buchmann, B., Peter, T., and Baltensperger, U.: Ground-based and airborne in-situ measurements of the Eyjafjallajökull volcanic aerosol plume in Switzerland in spring 2010, Atmos. Chem. Phys. Discuss., 11, 12949-13002, doi:10.5194/acpd-11-129492011, 2011.

Colette, A., Favez, O., Meleux, F., Chlappini, L., Haeffelin, M., Morille, Y., Malherbe, L., Papin, A., Bessagnet B., Menut, L., Leoz, E., and Rouil, L.: Assessing in near real time the impact of the April 2010 Eyjafjallajökull ash plume on air quality, Atmos. Environ., 45(5), 1217-1221, doi:10.1016/j.atmosenv.2010.09.064, 2010.

Craig, L., Brook, J.R., Chiotti, Q., Croes, B., Gower, S., and Hedley, A.: Air pollution and public health: a guidance document for risk managers, J. Toxicol. Environ. Health A, 71(9-10), 588698, 2008.

Cyrys, J., Pitz, M., Heinrich, J., Wichmann, H. E., and Peters, A.: Spatial and temporal variation of aerosol number concentration in Augsburg, Germany, Sci. Total Environ., 401, 168-175, 2008.

DIN EN 14902: Ambient air quality - Standard method for the measurement of $\mathrm{Pb}, \mathrm{Cd}, \mathrm{As}$ and $\mathrm{Ni}$ in the $\mathrm{PM}_{10}$ fraction of suspended particulate matter, German version EN 14902, DIN German Institute for Standardization, Berlin, Germany, 2005.

Dockery, D.W.: Health effects of particulate air pollution, Ann. Epidemiol., 19(4), 257-263, 2009.

Draxler, R. R. and Rolph, G. D.: HYSPLIT (HYbrid Single-Particle Lagrangian Integrated Trajectory) Model, National Oceanic and Atmospheric Administration (NOAA), United States Department of Commerce, Air Resources Laboratory, Silver Spring, MD, USA, http://ready.arl.noaa.gov/HYSPLIT.php, 2011.

Elliot, A. J., Singh, N., Loveridge, P., Harcourt, S., Smith, S., Pnaiser, R., Kavanagh, K., Robertson, C., Ramsay, C. N., McMenamin, J., Kibble, A., Murray, V., Ibbotson, S., Catchpole, M., McCloskey, B., and Smith, G.E.: Syndromic surveillance to assess the potential public health impact of the Icelandic volcanic ash plume across the United Kingdom, April 2010, Euro Surveill., 15, 23, http://www.eurosurveillance.org/ViewArticle. aspx?ArticleId=19583, 2010.

Emeis, S. and Schäfer, K.: Remote sensing method to investigate boundary-layer structures relevant to air pollution, Bound. Lay. Meteorol., 121, 377-385, doi:10.1007/s10546-006-9068-2, 2006.

Emeis, S., Forkel, R., Junkermann, W., Schäfer, K., Flentje, H., Gilge, S., Fricke, W., Wiegner, M., Freudenthaler, V., Groß, S., Ries, L., Meinhardt, F., Münkel, C., Obleitner, F., and Suppan, P.: Measurement and simulation of the 16/17 April 2010 Eyjafjallajökull volcanic ash layer dispersion in the northern Alpine region, Atmos. Chem. Phys., 11, 2689-2701, doi:10.5194/acp11-2689-2011, 2011.

Flentje, H., Claude, H., Elste, T., Gilge, S., Köhler, U., PlassDülmer, C., Steinbrecht, W., Thomas, W., Werner, A., and Fricke, W.: The Eyjafjallajökull eruption in April 2010 - detection of volcanic plume using in-situ measurements, ozone sondes and lidar-ceilometer profiles, Atmos. Chem. Phys., 10, 10085- 
10092, doi:10.5194/acp-10-10085-2010, 2010.

Gasteiger, J., Groß, S., Freudenthaler, V., and Wiegner, M.: Volcanic ash from Iceland over Munich: mass concentration retrieved from ground-based remote sensing measurements, Atmos. Chem. Phys., 11, 2209-2223, doi:10.5194/acp-11-22092011, 2011.

Grattan, J. and Brayshay, M.: An Amazing and Portentous Summer: Environmental and Social Responses in Britain to the 1783 Eruption of an Iceland Volcano, Geogr. J., 161, 125-134, 1995.

Gudmundsson, G.: Respiratory health effects of volcanic ash with special reference to Iceland. A review, Clin. Respir. J., 5(1), 2-9, 2011.

Hamed, A., Birmili, W., Joutsensaari, J., Mikkonen, S., Asmi, A., Wehner, B., Spindler, G., Jaatinen, A., Wiedensohler, A., Korhonen, H., Lehtinen, K. E. J., and Laaksonen, A.: Changes in the production rate of secondary aerosol particles in Central Europe in view of decreasing $\mathrm{SO}_{2}$ emissions between 1996 and 2006, Atmos. Chem. Phys., 10, 1071-1091, doi:10.5194/acp-10-10712010, 2010.

Hansell, A. and Oppenheimer, C.: Health hazards from volcanic gases: a systematic literature review, Arch. Environ. Health, 59(12), 628-639, 2004.

Hansen, J., Laci, A., Ruedy, R., and Sato, M.: Potential climate impact of Mt. Pinatubo eruption, Geophys. Res. Lett., 19, 215218, 1992.

Heinold, B., Tegen, I., Wolke, R., Ansmann, A., Mattis, I., Minikin, A., Schumann, U., and Weinzierl, B.: Simulations of the 2010 Eyjafjallajökull volcanic ash dispersal over Europe using COSMO-MUSCAT, Atmos. Environ., doi:10.1016/j.atmosenv.2011.05.021, in press, 2011.

Heue, K. P., Brenninkmeijer, C. A. M., Baker, A. K., RautheSchöch, A., Walter, D., Wagner, T., Hörmann, C., Sihler, H., Dix, B., Frieß, U., Platt, U., Martinsson, B. G., van Velthoven, P. F. J., Zahn, A., and Ebinghaus, R.: $\mathrm{SO}_{2}$ and $\mathrm{BrO}$ observation in the plume of the Eyjafjallajökull volcano 2010: CARIBIC and GOME-2 retrievals, Atmos. Chem. Phys., 11, 2973-2989, doi:10.5194/acp-11-2973-2011, 2011.

Ilyinskaya, E., Tsanev, V. I., Martin, R. S., Oppenheimer, C., Le Blond, J., Sawyer, G. M., and Gudmundsson, M. T.: Near-source observations of aerosol size distributions in the eruptive plumes from Eyjafjallajökull volcano, March-April 2010, Atmos. Environ., 45, 3210-3216, 2011.

Junkermann, W.: An Ultralight Aircraft as Platform for Research in the Lower Troposphere: System Performance and First Results from Radiation Transfer Studies in Stratiform Aerosol Layers and Broken Cloud Conditions, J. Atmos. Ocean. Tech., 18, 934-946, 2001.

Kazil, J., Stier, P., Zhang, K., Quaas, J., Kinne, S., O’Donnell, D., Rast, S., Esch, M., Ferrachat, S., Lohmann, U., and Feichter, J.: Aerosol nucleation and its role for clouds and Earth's radiative forcing in the aerosol-climate model ECHAM5-HAM, Atmos. Chem. Phys., 10, 10733-10752, doi:10.5194/acp-1010733-2010, 2010.

Krabbe, S., Lutz-Holzhauer, C., and Stoll, S.: Ausbruch des Eyjafjallajökull im April 2010. Auswirkungen auf die Feinstaubkonzentrationen in Baden-Württemberg, LUBW Landesanstalt für Umwelt, Messungen und Naturschutz BadenWürttemberg, Karlsruhe, Germany, 69 pp., 2010.

Kulmala, M., Vehkamäki, H., Petäjä, T., Dal Maso, M., Lauri, A.,
Kerminen, V.-M., Birmili, W., and McMurry, P. H.: Formation and growth rates of ultrafine atmospheric particles: A review of observations, J. Aerosol Sci., 35, 143-176, 2004.

Langmann, B., Folch, A., Hensch, M., and Matthias, V.: Volcanic ash over Europe during the eruption of Eyjafjallajökull on Iceland, April-May 2010, Atmos. Environ., doi:10.1016/j.atmosenv.2011.03.054, in press, 2011.

Lettino, A., Caggiano, R., Fiore, S., Macchiato, M., Sabia, S., and Trippetta, S.: Eyjafjallajökull volcanic ash in southern italy, Atmos. Environ., doi:10.1016/j.atmosenv.2011.05.037, in press, 2011.

Longo, B. M., Yang, W., Green, J. B., Crosby, F. L., and Crosby, V. L.: Acute health effects associated with exposure to volcanic air pollution (vog) from increased activity at Kilauea Volcano in 2008, J. Toxicol. Environ. Health A, 73(20), 1370-1381, 2010.

Mannschreck, K., Gilge, S., Plass-Duelmer, C., Fricke, W., and Berresheim, H.: Assessment of the applicability of $\mathrm{NO}^{-\mathrm{NO}_{2}-}$ $\mathrm{O}_{3}$ photostationary state to long-term measurements at the Hohenpeissenberg GAW Station, Germany, Atmos. Chem. Phys., 4, 1265-1277, doi:10.5194/acp-4-1265-2004, 2004.

Miffre, A., David, G., Thomas, B., Rairoux, P., Fjaeraa, A. M., Kristiansen, N. I., and Stohl, A.: Volcanic aerosol optical properties and phase partitioning behavior after long-range advection characterized by UV-Lidar measurements, Atmos. Environ., doi:10.1016/j.atmosenv.2011.03.057, in press, 2011.

Naumova, E. N., Yepes, H., Griffiths, J. K., Sempertegui, F., Khurana, G., and Jagai, J. S.: Emergency room visits for respiratory conditions in children increased after Guagua Pichincha volcanic eruptions in April 2000 in Quito, Ecuador observational study: time series analysis, Environ. Health, 6(21), 1-11, doi:10.1186/1476-069X-6-21, 2007.

Paasonen, P., Nieminen, T., Asmi, E., Manninen, H. E., Petäjä, T., Plass-Dülmer, C., Flentje, H., Birmili, W., Wiedensohler, A., Hõrrak, U., Metzger, A., Hamed, A., Laaksonen, A., Facchini, M. C., Kerminen, V.-M., and Kulmala, M.: On the roles of sulphuric acid and low-volatility organic vapours in the initial steps of atmospheric new particle formation, Atmos. Chem. Phys., 10, 11223-11242, doi:10.5194/acp-10-11223-2010, 2010.

Parker, D. E., Wilson, H., Jones, P. D., Christy, J., and Folland, C. K.: The impact of Mount Pinatubo on climate, Int. J. Climatol., 16, 487-497, 1996.

Peters, A., Wichmann, H. E., Tuch, T., Heinrich, J., and Heyder, J.: Comparison of the number of ultrafine particles and the mass of fine particles with respiratory symptoms in asthmatics, Ann. Occup. Hyg., 41 (Suppl. 1), 19-23, 1997.

Petersen, G. N.: A short meteorological overview of the Eyjafjallajokull eruption 14 April-23 May 2010, Weather, Royal Meteorological Society, 65(8), 203-207, doi:10.1002/wea.634, 2010.

Pitz, M., Birmili, W., Schmid, O., Peters, A., Wichmann, H. E., and Cyrys, J.: Quality control and quality assurance for particle size distribution measurements at an urban monitoring station in Augsburg, Germany, J. Env. Monitoring, 10, 1017-1024, 2008a.

Pitz, M., Schmid, O., Heinrich, J., Birmili, W., Maguhn, J., Zimmermann, R., Wichmann, H.E., Peters, A., and Cyrys, J.: Seasonal and diurnal variation of PM2.5 apparent particle density in urban air in Augsburg, Germany, Environ. Sci. Technol., 42, 5087-5093, 2008b.

Pitz, M., Gu, J., Soentgen, J., Peters, A., and Cyrys, J.: Particle size distribution factor as an indicator for the impact of 
the Eyjafjallajökull ash plume at ground level in Augsburg, Germany, Atmos. Chem. Phys. Discuss., 11, 16417-16437, doi:10.5194/acpd-11-16417-2011, 2011.

Prata, A. J.: Observations of volcanic ash clouds in the $10-12 \mu \mathrm{m}$ window using AVHRR/2 data, Int. J. Remote Sens., 10, 751-761, 1989.

Prata, A. J. and Kerkmann, J.: Simultaneous retrieval of volcanic ash and $\mathrm{SO}_{2}$ using MSG-SEVIRI measurements, Geophys. Res. Lett., 34, L05813, doi:10.1029/2006GL028691, 2007.

Revuelta, M.A., Sastre, M., Fernández, A.J., Martin, L., García, R., Gomez-Moreno, F.J., Artiñano, B., Pujadas, M., and Molero, F.: Characterization of the Eyjafjallajökull volcanic plume over the Iberian Peninsula by lidar remote sensing and ground level data collection, Atmos. Environ., doi:10.1016/j.atmosenv.2011.05.033, in press, 2011.

Rossini, P., Molinaroli, E., De Falco, G., Fiesoletti, F., Papa, S., Pari, E., Renzulli, A., Tentoni, P., Testoni, A., Valentini, A., and Matteucci, G.: April-May 2010 Eyjafjallajökull volcanic fallout over Rimini, Italy, Atmos. Environ., doi:10.1016/j.atmosenv.2011.05.018, in press, 2011.

Schmetz, J., Pili, P., Tejmkes, S., Just, D., and Kerkmann, J.: An introduction to METEOSAT second generation (MSG), Bulletin of the American Meteorological Society, American Meteorological Society, Boston, MD, USA, 83(7), 977-992, doi:110.1175/BAMS-83-7-Schmetz-1, 2002.

Schleicher, N., Kramar, U., Dietze, V., Kaminski, U., and Norra, S.: Geochemical characterization of single atmospheric particles from the Eyjafjallajökull volcano eruption event collected at ground-based sampling sites in Germany, Atmospheric Environment, doi:10.1016/j.atmosenv.2011.05.034, in press, 2011.

Schumann, U., Weinzierl, B., Reitebuch, O., Schlager, H., Minikin, A., Forster, C., Baumann, R., Sailer, T., Graf, K., Mannstein, H., Voigt, C., Rahm, S., Simmet, R., Scheibe, M., Lichtenstern, M., Stock, P., Rüba, H., Schäuble, D., Tafferner, A., Rautenhaus, M., Gerz, T., Ziereis, H., Krautstrunk, M., Mallaun, C., Gayet, J.-F., Lieke, K., Kandler, K., Ebert, M., Weinbruch, S., Stohl, A., Gasteiger, J., Groß, S., Freudenthaler, V., Wiegner, M., Ansmann, A., Tesche, M., Olafsson, H., and Sturm, K.: Airborne observations of the Eyjafjalla volcano ash cloud over Europe during air space closure in April and May 2010, Atmos. Chem. Phys., 11, 2245-2279, doi:10.5194/acp-11-2245-2011, 2011.

Shimizu, Y., Dobashi, K., Hisada, T., Ono, A., Todokoro, M., and Iijima, H.: Acute impact of volcanic ash on asthma symptoms and treatment, Int. J. Immunopathol. Pharmacol., 20, 2 (Suppl 2), 9-14, 2007.

Stohl, A., Prata, A.J., Eckhardt, S., Clarisse, L., Durant, A., Henne, S., Kristiansen, N.I., Minikin, A., Schumann, U., Seibert, P., Stebel, K., Thomas, H.E., Thorsteinsson, T., Tørseth K., and Weinzierl, B.: Determination of time- and height-resolved volcanic ash emissions and their use for quantitative ash dispersion modeling: the 2010 Eyjafjallajökull eruption, Atmos. Chem. Phys., 11, 4333-4351, doi:10.5194/acp-11-4333-2011, 2011.
Thomas, H. E. and Prata, A. J.: Sulphur dioxide as a volcanic ash proxy during the April-May 2010 eruption of Eyjafjallajökull Volcano, Iceland, Atmos. Chem. Phys., 11, 6871-6880, doi:10.5194/acp-11-6871-2011, 2011

Thordarson, T. and Self, S.: The Laki (Skaftár Fires) and Grímsvötn eruptions in 1783-1785, B. Volcanol., 55, 233-263, 1993.

Thordarson, T. and Self, S.: Atmospheric and environmental effects of the 1783-1784 Laki eruption: A review and reassessment, J. Geophys. Res., 108(D1), 4011, doi:10.1029/2001JD002042, 2003.

Tong, H., Cheng, W. Y., Samet, J. M., Gilmour, M. I., and Devlin, R. B.: Differential cardiopulmonary effects of size-fractionated ambient particulate matter in mice, Cardiovasc. Toxicol., 10(4), 259-267, 2010.

UBA: Luftbelastungssituation 2010 - vorläufige Auswertung, http: //www.umweltdaten.de/publikationen/fpdf-1/4063.pdf, 2011.

Vanderstraeten, P., Le'nelle, Y., Meurrens, A., Carati, D., Brenig, L., Delcloo, A., Offer, Z.Y., and Zaady, E.: Dust storm originate from Sahara covering Western Europe: A case study, Atmos. Environ., 42, 5489-5493, 2008.

Warneck, P.: Sulphur Dioxide and Particulate Sulfate, in: Chemistry of the Natural Atmosphere, International Geophysics Series, 41, edited by: Dmowska, R. and Holton, J. R., Academic Press, London, UK, 505-535, 1988.

Wiedensohler, A., Birmili, W., Nowak, A., Sonntag, A., Weinhold, K., Merkel, M., Wehner, B., Tuch, T., Pfeifer, S., Fiebig, M., Fjäraa, A. M., Asmi, E., Sellegri, K., Depuy, R., Venzac, H., Villani, P., Laj, P., Aalto, P., Ogren, J. A., Swietlicki, E., Roldin, P., Williams, P., Quincey, P., Hglin, C., Fierz-Schmidhauser, R., Gysel, M., Weingartner, E., Riccobono, F., Santos, S., Grning, C., Faloon, K., Beddows, D., Harrison, R. M., Monahan, C., Jennings, S. G., O’Dowd, C. D., Marinoni, A., Horn, H.-G., Keck, L., Jiang, J., Scheckman, J., McMurry, P. H., Deng, Z., Zhao, C. S., Moerman, M., Henzing, B., and de Leeuw, G.: Particle mobility size spectrometers: harmonization of technical standards and data structure to facilitate high quality long-term observations of atmospheric particle number size distributions, Atmos. Meas. Tech. Discuss., 3, 5521-5587, doi:10.5194/amtd-3-55212010, 2010.

Williams-Jones, G. and Rymer, H.: Hazards of volcanic gases, in: Encyclopedia of Volcanoes, Academic Press, San-Diego, USA, 997-1004, 2000.

Zanobetti, A. and Schwartz, J.: The effect of fine and coarse particulate air pollution on mortality: a national analysis, Environ. Health Perspect., 117(6), 898-903, 2009. 